\title{
Infectious Encephalitis in the Neurocritical Care Unit
}

\author{
Luisa A. Diaz-Arias, MD \\ Carlos A. Pardo, MD \\ John C. Probasco, $M D^{*}$
}

\author{
Address \\ *Department of Neurology, Johns Hopkins University School of Medicine, $600 \mathrm{~N}$. \\ Wolfe St., Meyer 6-113, Baltimore, MD, 21287, USA \\ Email: jprobas1@jhmi.edu
}

Published online: 28 May 2020

(C) Springer Science+Business Media, LLC, part of Springer Nature 2020

\section{This article is part of the Topical Collection on Critical Care Neurology}

Keywords Encephalitis · Infectious · Neurocritical care $\cdot$ Intensive care $\cdot$ HSV encephalitis · TB encephalitis

\begin{abstract}
Purpose of review Infectious encephalitis is a rapidly progressive encephalopathy caused by a variety of pathogens, most commonly viruses. It is associated with significant mortality and morbidity, often requiring evaluation and treatment in the intensive care unit. This review article discusses the diagnosis of the infectious etiologies, the assessment for differential diagnoses, and the initiation of therapies, and most importantly, it entails the rapid and efficient management of the associated complications.

Recent findings Novel emerging technologies (e.g., metagenomic next-generation sequencing) have the potential to assist in the diagnosis, etiology identification, and treatment of encephalitis. Interventions such as ketogenic diet therapies have been promising in their potential to treat patients with refractory status epilepticus in the setting of infectious encephalitides.

Summary Early recognition of encephalitis and appropriate treatment of the primary infection and its complications are essential to increase survival and reduce sequelae. Intensivists are crucial given the high mortality rate of infectious encephalitis in the ICU setting, and their role may significantly impact patients' outcomes.
\end{abstract}

\section{Introduction}

Infectious encephalitis frequently evolves as an acute inflammation of the brain parenchyma due to a viral, bacterial, fungal, or parasitic infection. [1] Acute infectious encephalitis often requires assessment in the intensive care unit (ICU) due to the magnitude of the neuroinflammatory process and associated complications. Mortality, morbidity, and prognosis are influenced not only by specific etiologies, but also the complications that emerge during the disease process. In this review article, we will discuss the epidemiology, 
etiology, clinical manifestations, diagnostic assessment, treatment options, and complications for common infectious encephalitides encountered in the critical care setting, as well as the management of these complications.

\section{Definition}

\section{Epidemiology}

Acute infectious encephalitis emerges as an inflammation of the brain parenchyma, clinically manifested by altered mental status for more than $24 \mathrm{~h}$ and at least two of the following criteria: fever up to $38{ }^{\circ} \mathrm{C}$ before or after presentation, new onset of seizures, focal neurologic deficits, cerebrospinal fluid (CSF) pleocytosis, and electroencephalogram or neuroimaging abnormalities consistent with the diagnosis of encephalitis. [2•,3]

Encephalitis can be classified by etiology, namely infectious, post-infectious, or autoimmune. Although infectious encephalitides have been historically considered as the most frequent type, particularly viral; there is increased recognition of autoimmune etiologies. [4] Of note, some infections may trigger post-infectious encephalitides, such as acute disseminated encephalomyelitis (ADEM), autoimmune encephalitides including anti-N-methyl-D-aspartate receptor (NMDAR) encephalitis or autoimmune responses such as myelin oligodendrocyte (MOG)-associated disorders. [5-7]

The incidence of infectious encephalitis varies according to geography and affected populations (e.g., immunocompromised and vulnerable persons [children and the elderly]). The annual incidence of infectious encephalitis is an estimated 1 per 100,000 person-years, with 60\% of cases being viral, particularly among children. [4] More than 50\% of cases remain without an identified pathogen; nevertheless, the development of new molecular techniques for pathogen discovery has improved the rate etiological diagnosis. $[8,9 \bullet \bullet]$

Viral encephalitis may be due to either DNA or RNA viruses, which have various modes of transmission, including bloodborne, airborne, or mosquitoborne. Ecological, environmental, and host-dependent factors are critical in the epidemiology of viral encephalitis. A patient's travel history and geographic location may suggest the etiology such as West Nile Virus in the USA or Dengue in South America. $[10,11]$ In addition, the presence of an immunosuppressive state can predispose to opportunistic infections, particularly those produced by DNA viruses. [12]

\section{Etiology}

\section{Viruses}

\section{DNA Viruses}

Among the DNA viruses, herpesviruses are the most frequently identified pathogen of viral encephalitis. [13] There are more than 100 known 
herpesviruses, but only seven may produce encephalitis, namely herpes simplex virus, varicella zoster virus, Epstein-Barr virus, cytomegalovirus, human herpesvirus 6, and, rarely, human herpesvirus 7 and human herpesvirus 8 .

Herpes simplex virus

HSV is the most recognized cause of infectious encephalitis worldwide. HSV encephalitis is almost exclusively caused by HSV-1, except in newborns, among whom HSV-2 is more prevalent. This virus has a bimodal pattern of presentation, one in early childhood and another among those older than 50 years of age. [14]

Patients develop an acute course of fever, confusion, altered behavior, headaches, dysphasia, and cranial neuropathies. Seizures affect $85 \%$ of patients, particularly younger patients, and 33\% of people may become comatose. [15] Magnetic resonance imaging (MRI) of the brain is abnormal in $90 \%$ of cases, demonstrating cytotoxic and vasogenic edema in the medial and inferior temporal lobes (Fig. 1). Therapy should be initiated with acyclovir and its discontinuation requires a second CSF study to reevaluate HSV DNA presence. [16, 17, 18•]

VZV is the second most significant cause of viral encephalitis after HSV. [3] VZV encephalitis may affect children 1 week after primary varicella infection, as well as immunosuppressed and older adult patients. [19] A portion of patients develops VZV encephalitis in the setting of acute varicella, while others have neurological symptoms in the absence of the rash. Neurological symptoms include altered consciousness, focal neurological signs, cranial neuropathies, and convulsions. [19]

Brain MRI demonstrates areas of T2 hyperintensities and areas of restricted diffusion in the basal ganglia, thalami, cerebellum, temporal lobes, and



Fig. 1. Brain MRI of a patient with HSV-1 encephalitis. a FLAIR sequence demonstrates T2 hyperintensities of the right mesial temporal lobe including the hippocampus, amygdala, and anteroinferior temporal lobe with associated gyriform swelling. $\mathbf{b}$ Diffusion-weighted imaging sequence demonstrates restricted diffusion in the same structures as well as within the left anterior temporal lobe. c T1-post-gadolinium sequence demonstrates leptomeningeal enhancement as well as subtle enhancement of the right hippocampus. 
cerebral cortex. In addition, hemorrhages, ischemia, and vasculopathy may be present. [20] Therapy includes acyclovir; however, clinical trial data do not exist to support this approach. [18 $\bullet, 21,22]$ Ganciclovir can be considered as an alternative. [18•, 23]

\section{RNA viruses}

RNA viruses have a rapid rate of mutagenesis and genomic variation, properties that have played an important evolutionary role. [24] Among the most frequent RNA viruses that produce encephalitis are enteroviruses; influenza; arboviruses; HIV; and more recently emerging and re-emerging viruses such as rabies, mumps, measles, and ebola.

Enteroviruses are a group of viruses that produce several mild infectious diseases and frequently affect children. Strains associated with central nervous system (CNS) impairment include EV-A71, A75, A76, A89, and D68; coxsackievirus A9 and A10; echovirus 4, 5, 9, 11, 19, 30; and human parechovirus 3. [25] Encephalitis is typically rare and mild compared with other etiologies. Approximately $25 \%$ of patients present with focal neurological deficits, while less than $10 \%$ of patients have severe deterioration of mental status and seizures. [26]

Enterovirus A71 (EV-A71) is exceptional in that it may cause rhombencephalitis with a more fulminant course. $[27,28]$ EV-A71 is a frequent pathogen in Southeast Asia, but clusters of EV-A71 have been reported recently in the USA. [29] EV-A71 encephalitis manifests with cranial neuropathies, respiratory failure, movement disorders and ataxia. [30] Brain MRI is abnormal in approximately $50 \%$ of cases, typically involving the temporal lobes. $[3,31]$ There is no specific treatment for enterovirus encephalitis, but there are anecdotal reports of some antiviral treatments such as pleconaril and ribavirin. $[18 \bullet, 25]$

Arboviruses are a family of viruses transmitted to humans through a mosquito or tick bite. [32] Outbreaks depend on vector presence and geographic distribution. The infection may be completely asymptomatic, produce systemic manifestations or neurological syndromes. Among the most frequent neurological syndromes are meningitis, encephalitis, and less frequently, peripheral neuropathy or myelopathy with a preference for the anterior horn cells (e.g., acute flaccid paralysis). [33]

WNV is a mosquito-borne flavivirus that represents a frequent cause of viral encephalitis in the USA, Europe, and North Africa, affecting primarily elderly and immunocompromised patients. $[11,34]$. Encephalitis is the most common neurologic presentation of WNV, accounting for $60 \%$ of neuroinvasive WNV infection. Common manifestations include 
movement disorders and cranial neuropathies. [11] Mild lower motor neuron symptoms may also occur, even in the absence of acute flaccid paralysis. [3, 33] This condition commonly shows a neutrophilic CSF pleocytosis during the first week. MRI is abnormal in $66 \%$ of cases, typically demonstrating lesions in the basal ganglia, thalami, temporal lobes, cerebellum, leptomeninges, and ventricles. [35] Specific treatment is not available, and management is mainly supportive. [18 $]$

HIV infection and AIDS may be associated with acute neurological emergencies presenting as HIV encephalitis, opportunistic infections, or other forms of acute immune-mediated manifestations as the result of immune reconstitution after antiretroviral therapy (ART). The epidemiology of these HIV-associated complications has changed dramatically with the introduction of ART at the end of the twentieth century. While the epidemiology of HIV-associated neurological complications is influenced by socioeconomic and environmental factors in different areas of the world, HIVrelated opportunistic infections, HIV-associated CNS neoplasms and immune reconstitution syndrome (IRIS) are the most frequent HIV-related disorders in the critical care setting regardless of such factors. [36, 37]

a) Intracranial opportunistic infections associated with HIV

During the early stage of AIDS and/or stages of immunosuppression due to the marked decrease of CD4+ lymphocytes and increased HIV viral load, several opportunistic infections have the potential to affect the CNS. Most of these infections include DNA viruses such as JCV, VZV, CMV, and EBV as well as bacteria (e.g., Mycobacterium tuberculosis), fungi (e.g., Cryptococcus neoformans, Candida albicans, Aspergillus, Histoplasma, and Coccidioides), and parasites (e.g., Toxoplasma gondii).

b) Immune reconstitution syndrome (IRIS) as an encephalitic manifestation in HIV infection

IRIS is a group of inflammatory disorders associated with a paradoxical worsening of neuroinflammatory responses after treatment with ART and control of preexisting opportunistic infections. $[38,39]$ Retrospective case series suggest that up to $30 \%$ of HIV patients treated with ART develop one or more inflammatory syndromes. [40-42] Clinical manifestations follow a subacute or chronic course succeeding the initiation of ART and depend on the type of preexisting opportunistic infection. [43] For instance, patients with a previous cryptococcal infection could develop fever, gastrointestinal symptoms, eye pain, and meningismus, while patients with M. avium complex may experience expansion of preexisting intracranial tuberculomas. $[44,45]$

Although there are no well-established diagnostic criteria of IRIS, the diagnosis could be made if patients satisfy the following features: the presence of AIDS with a CD4 count of less than 100 cells/ $\mu \mathrm{L}$; viral or immune response to ART; absence of drug-resistant infection, bacterial infection, or drug allergy; the presence of clinical features compatible with an inflammatory disorder; and timeframe consistent with IRIS. [40, 46] Management requires the continuation of ART and urgent treatment of the underlying 
Bacteria

opportunistic infection whether it is still present.

\section{Mycobacterium tuberculosis}

Mycobacterium tuberculosis is one of the most serious opportunistic infections in HIV patients and transplants. In 2018, approximately 10 million people had tuberculosis (TB) and about $17 \%$ of these patients presented with extrapulmonary disease. [47, 48] In HIV-positive patients, this figure reaches $40 \%$ due to their risk of CNS involvement is five times higher than in HIV-negative individuals. $[49,50]$ The clinical presentation is usually mild at the beginning of the infection and includes severe headache, fever, unbalance, altered consciousness, and cognitive impairment. $[47,51]$

CSF analyses typically demonstrate hyperproteinorachie, lymphocytic pleocytosis, and hypoglycorrhachia. $[47,52]$ The use of PCR based techniques and Quantitative Xpert MTB/RIF PCR as a diagnostic tool have been preferred above CSF cultures, despite a relatively low yield of diagnosis. [53-56] Brain MRI is commonly normal, but cases of granulomas and brain abscess have been described. [47] Treatment consists of 6-month therapy with isoniazid, rifampicin, pyrazinamide, and ethambutol. [18•] Corticosteroids may improve outcomes related to brain edema and vasculitis in patients with meningitis. [57, $58]$

\section{Cryptococcus}

Cryptococcus is an encapsulated yeast that causes one million cases of the Cryptococcus-associated neurological complications per year, resulting in about 600.000 deaths. [59, 60] Meningitis, encephalitis, or meningoencephalitis are considered the most common causes of life-threatening fungal infection. The majority of cases of cryptococcal encephalitis are seen among severely immunocompromised patients with AIDS and CD4 count of less than 100 cells/ $\mu \mathrm{l}$, or HIV patients with antiretroviral-drug resistance or poor adherence.

Patients may present with an acute or chronic course of headaches, behavioral changes, cognitive impairment, and lethargy. Approximately $30 \%$ of patients may have normal CSF findings, but elevated opening pressure is present in more than 50\% of cases. [61-63] Cryptococcal antigen testing in serum and CSF confirms the diagnosis and is sufficient for treatment initiation, but a confirmatory cryptococcal culture should be performed. Brain MRI may show lesions in the basal ganglia suggesting cysts, nodules, and leptomeningeal enhancement. Imaging may suggest intracranial hypertension with or without space-occupying lesions and hydrocephalus.

The treatment regimen consists of the aggressive administration of antifungal agents with therapeutic relief of elevated intracranial pressure by serial lumbar punctures or ventricular drainage. The treatment includes the use of amphotericin B, flucytosine, and fluconazole in three different stages of therapy (induction, consolidation, and maintenance). The use of corticosteroid treatment during the Cryptococcus-associated complications may prevent vasculitic or inflammatory processes. [64] 


\section{Parasites}

\section{Toxoplasma gondii}

Toxoplasma gondii is a parasite that potentially affects the brain of AIDS patients as the by-product of a reactivation of a chronic infection. Of note, $10-40 \%$ of HIV-infected patients who have antibodies against $T$. gondii are susceptible to toxoplasmic encephalitis. [65] The epidemiology of T. gondii in patients with HIV/AIDS has changed from 10,000 hospitalization per year in 1995 to 2985 in 2008 due to the introduction of prophylaxis treatment and ART. [66, 67] Clinical manifestations include a subacute onset of language dysfunction, weakness, headache, altered consciousness and fever.

Diagnosis requires the identification of Toxoplasma IgG and IgM antibodies, parasite isolation from body fluids or tissues or amplification through RTPCR. Although there are no pathognomonic findings in imaging, CT scan may demonstrate lesions in the basal ganglia and subcortical regions with associated enhancement in $80 \%$ of patients. [68-70] Treatment includes the use of pyrimethamine and sulfadiazine. [18 ] Corticosteroids in the setting of cerebral edema and intracranial hypertension are recommended for no more than 2 weeks.

\section{Diagnosis and laboratory approach in the ICU}

Encephalitis should be a consideration in a patient who presents with altered consciousness, fever, cranial neuropathies, movement disorders, meningismus, seizures, and/or new focal neurological deficits. In addition to a comprehensive clinical examination, the intensivist should assess for complications such as seizures or status epilepticus, brain edema, hydrocephalus, systemic metabolic disturbances, or infections when managing patients with encephalitis in the ICU. Several diagnostic modalities are available for a comprehensive evaluation of patients with concern for encephalitis, including infectious encephalitis. Diverse techniques include imaging techniques (e.g., CT and brain MRI, FDGPET scan), neurophysiological methods (e.g., electroencephalography [EEG] monitoring, nerve conduction studies [NCS] and electromyography [EMG]), laboratory testing of blood, CSF, and other biological samples to establish an etiology, treatment, and monitoring for potential complications.

Rapid brain imaging with CT scan is an important initial test to evaluate for brain edema, intracranial hypertension, hydrocephalus, and brain herniation. Brain MRI is always a helpful tool to support the diagnosis of encephalitis, assessing the burden of brain and brainstem involvement as well as providing clues for possible causes. The most pertinent MRI sequences in encephalitis are T2-weighted images, fluid-attenuated inversion recovery (FLAIR), gradient-echo or susceptibility-weighted imaging, and postgadolinium sequences. [71] Despite limited logistic resources in the ICU, PET-based techniques such as FDG-PET/CT may be of value in evaluating etiologies (namely autoimmune encephalitides) or assessment of brain physiology; however, experience with FDG-PET/CT in infectious 
encephalitides is largely restricted to tertiary centers and case reports. [72, $73 \bullet, 74-76$ ] Future study is needed to determine the utility of FDG-PET/CT in the diagnosis and clinical monitoring of infectious encephalitides as well as the differentiation from autoimmune encephalitis and other causes of subacute cognitive decline. Empiric antimicrobial therapy should be started in those patients with suspected infectious encephalitis until laboratory tests are available to guide discontinuation. [33]

Lumbar puncture for evaluation of opening pressure and CSF analyses are critical tools in the ICU setting. The initial approach for CSF analysis should include a comprehensive assessment of potential etiologies and include the proper microbiological tests such as bacterial or fungal cultures as well as specific molecular and immunological studies used for specific pathogens (Table 1). Early and efficient detection of pathogens by PCR or immunological tests are influenced by different factors including the timing of the infection, duration of symptoms, and CSF sampling, thus negative results should be interpreted carefully and account for such factors. [3] CSF markers including oligoclonal bands and IgG index are valuable in the assessment for neuroinflammation and always should be included during the initial assessment. In the setting of preceding respiratory tract infections, cultures or molecular assays (e.g., PCR) of nasopharyngeal swabs or aspirates should be always part of the evaluation.

Blood tests to consider include HIV serologies to assess for HIV infection and immune status, complete blood cell counts with differential analyses of cells, complete metabolic panels to evaluate for renal and hepatic involvement, and bacterial blood cultures. Serum electrolyte levels to identify electrolyte disorders (e.g., 25\% of patients with St. Louis encephalitis develop inappropriate secretion of antidiuretic hormone). Blood urea nitrogen and creatinine levels are useful to assess hydration status and adjust antimicrobial therapy. [163] Urine or serum toxicology testing may be helpful in patients with toxic delirium or confusional state. [164]

If CSF and imaging suggest encephalitis, and microbiology tests are nonrevealing, paraneoplastic and autoimmune causes should be considered. When autoimmune or paraneoplastic encephalitis is a consideration, both serum and CSF evaluation for anti-neuronal autoantibodies should be included (e.g., anti-NMDAR, anti-LGI1, anti-AMPAR, GAD65, GABA-A, and GABA-B). Absence of antibodies does not rule out the disease. CT of the chest, abdomen, pelvis; tumor markers; gonadal ultrasound; and FDGPET studies should be considered to rule out occult malignancy or other systemic sources of infection. [165]

Novel emerging technologies include molecular-based assays such as BioFire FilmArray ${ }^{\circledR}$ Panels (BioFire/bioMérieux, Salt Lake City, USA) and metagenomic next-generation sequencing (mNGs). The FilmArray ${ }^{\circledR}$ panels are focused PCR-multiplexed assays which include a meningitis/ encephalitis panel for testing fourteen frequent microorganisms and viruses that cause meningitis and encephalitis. [166] Although the panel's sensitivity and specificity are high, its availability is still limited and many pathogens are not included in the panel. [167, 168, 169••] 


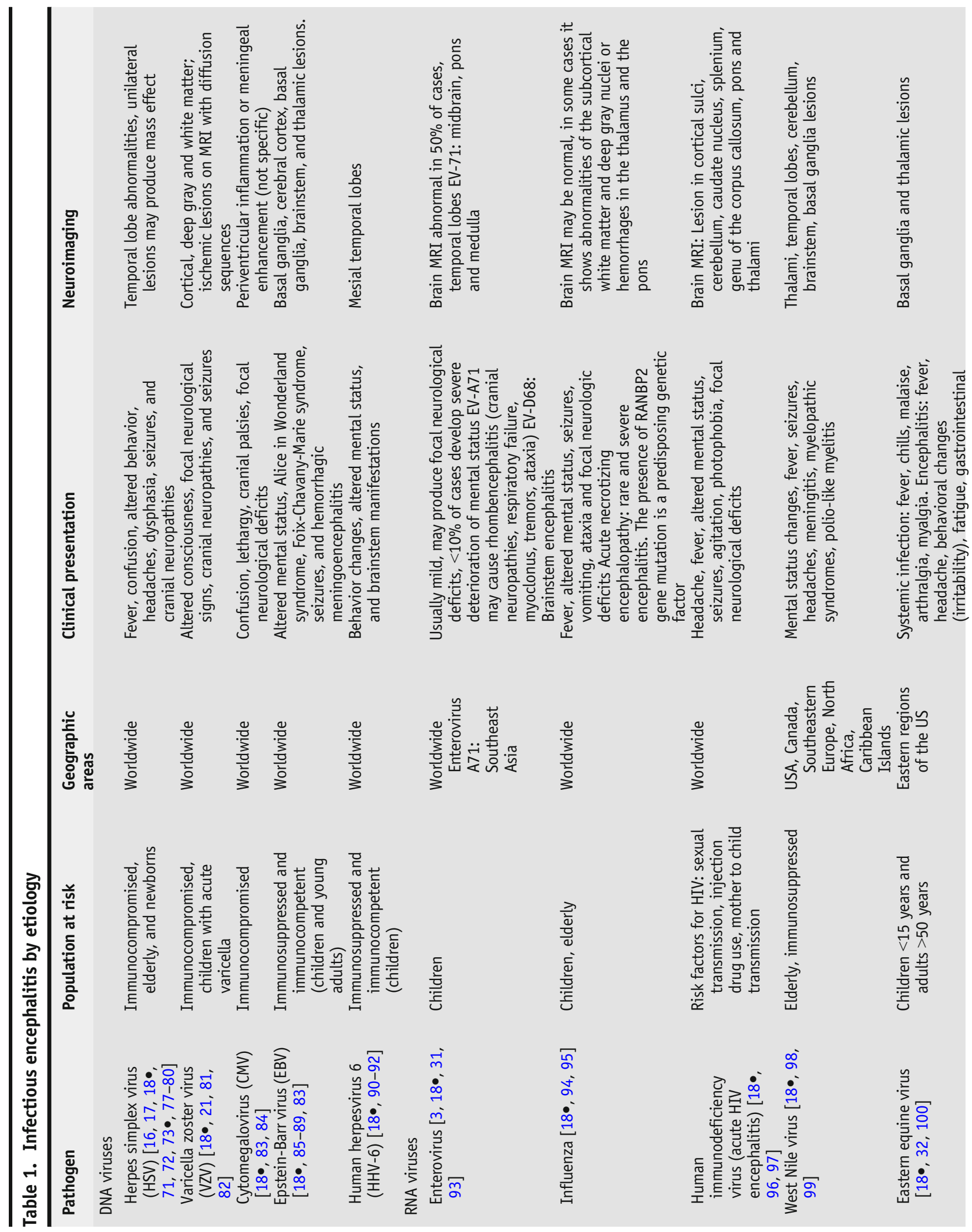



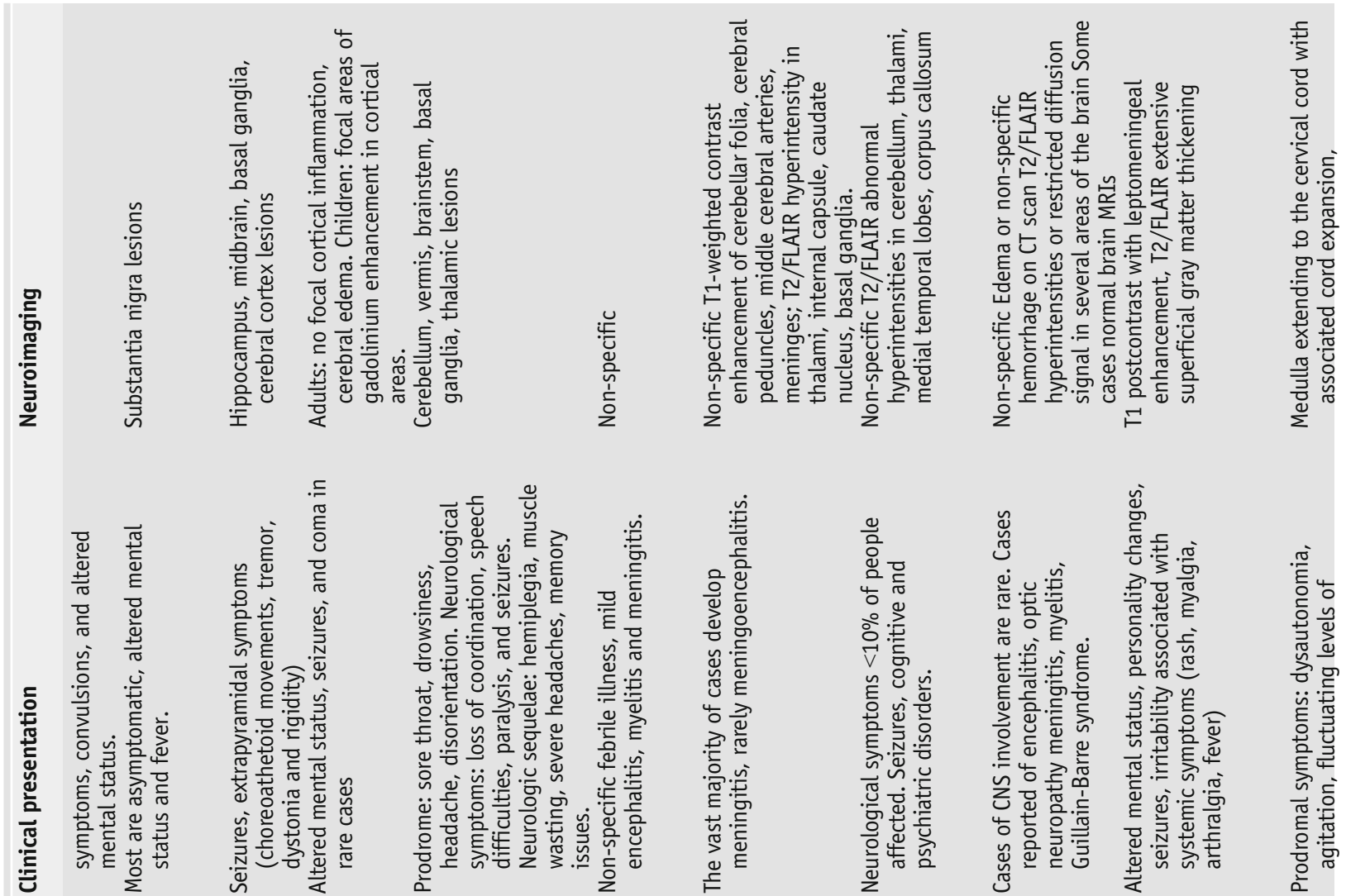

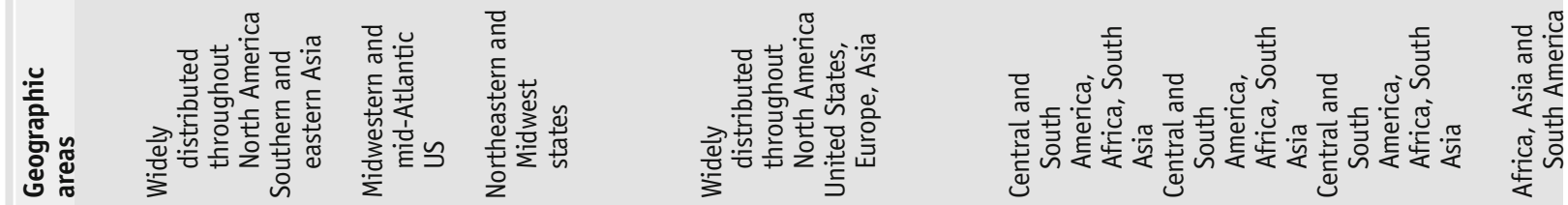
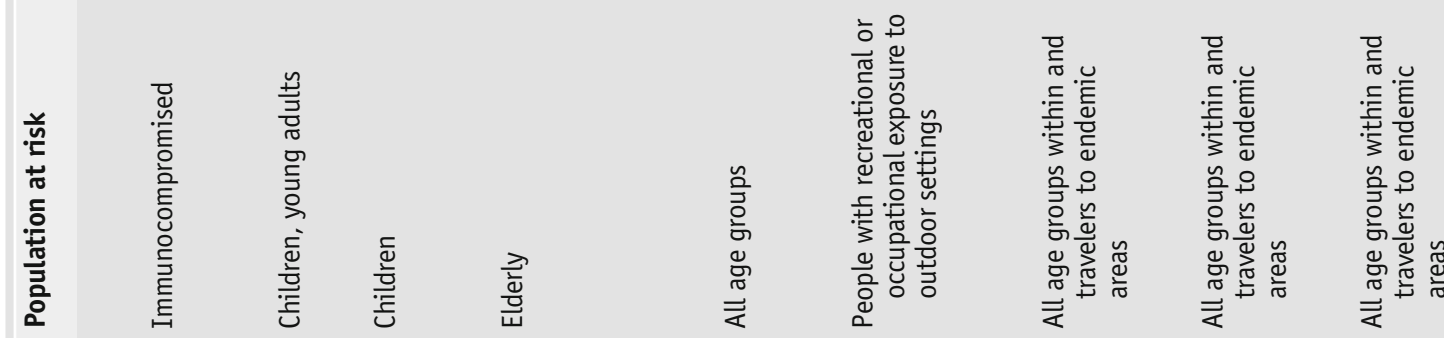

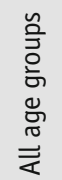
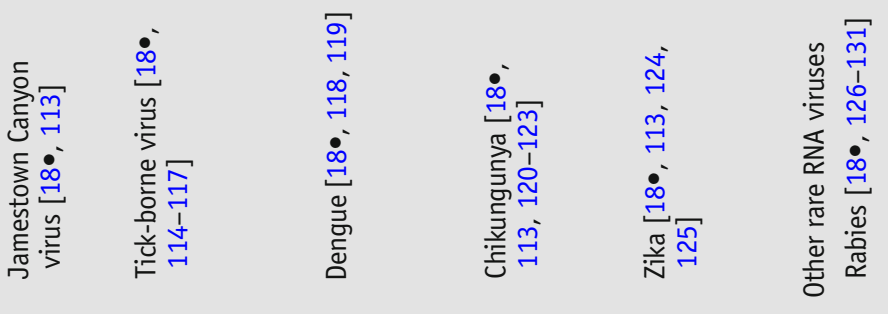

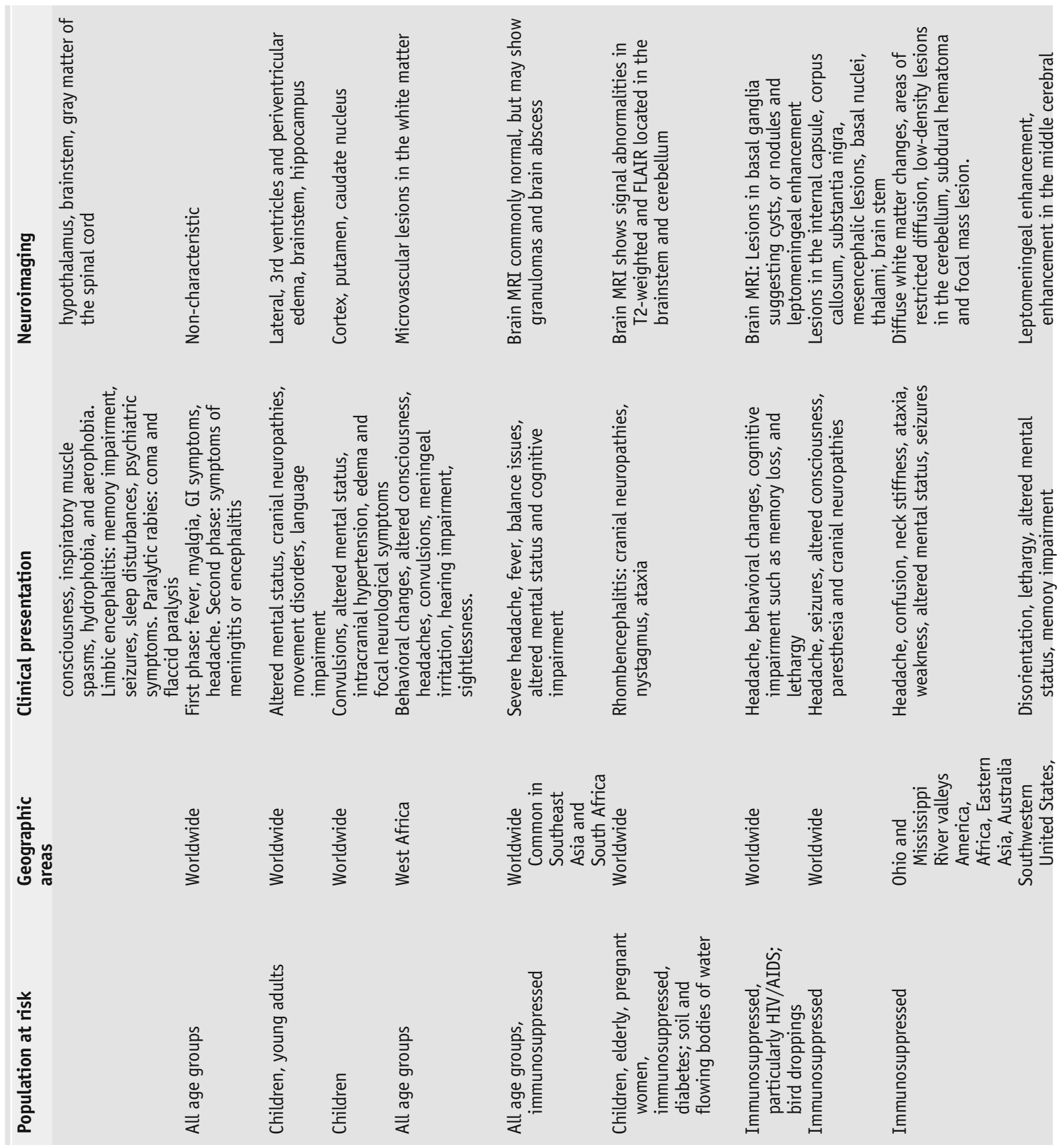

\begin{tabular}{|c|c|c|c|c|c|c|c|c|}
\hline 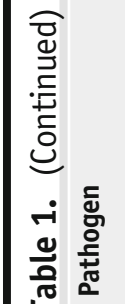 & 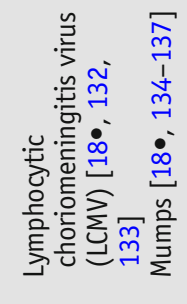 &  & 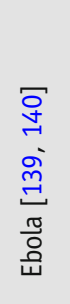 & 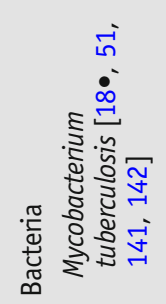 & 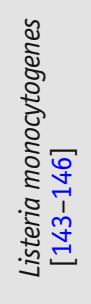 & 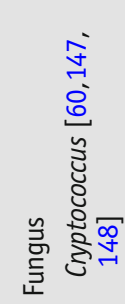 &  & 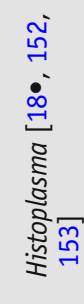 \\
\hline
\end{tabular}









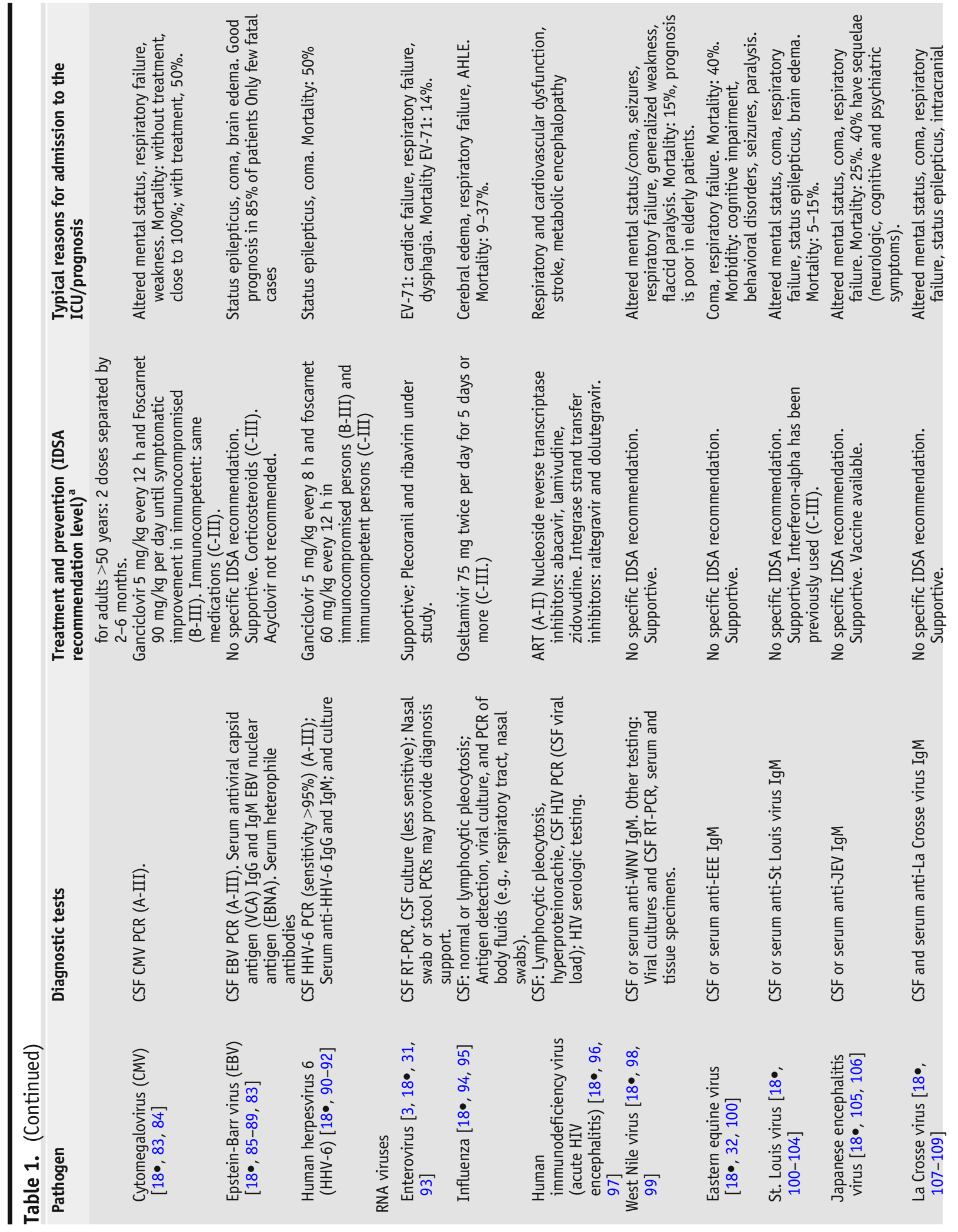



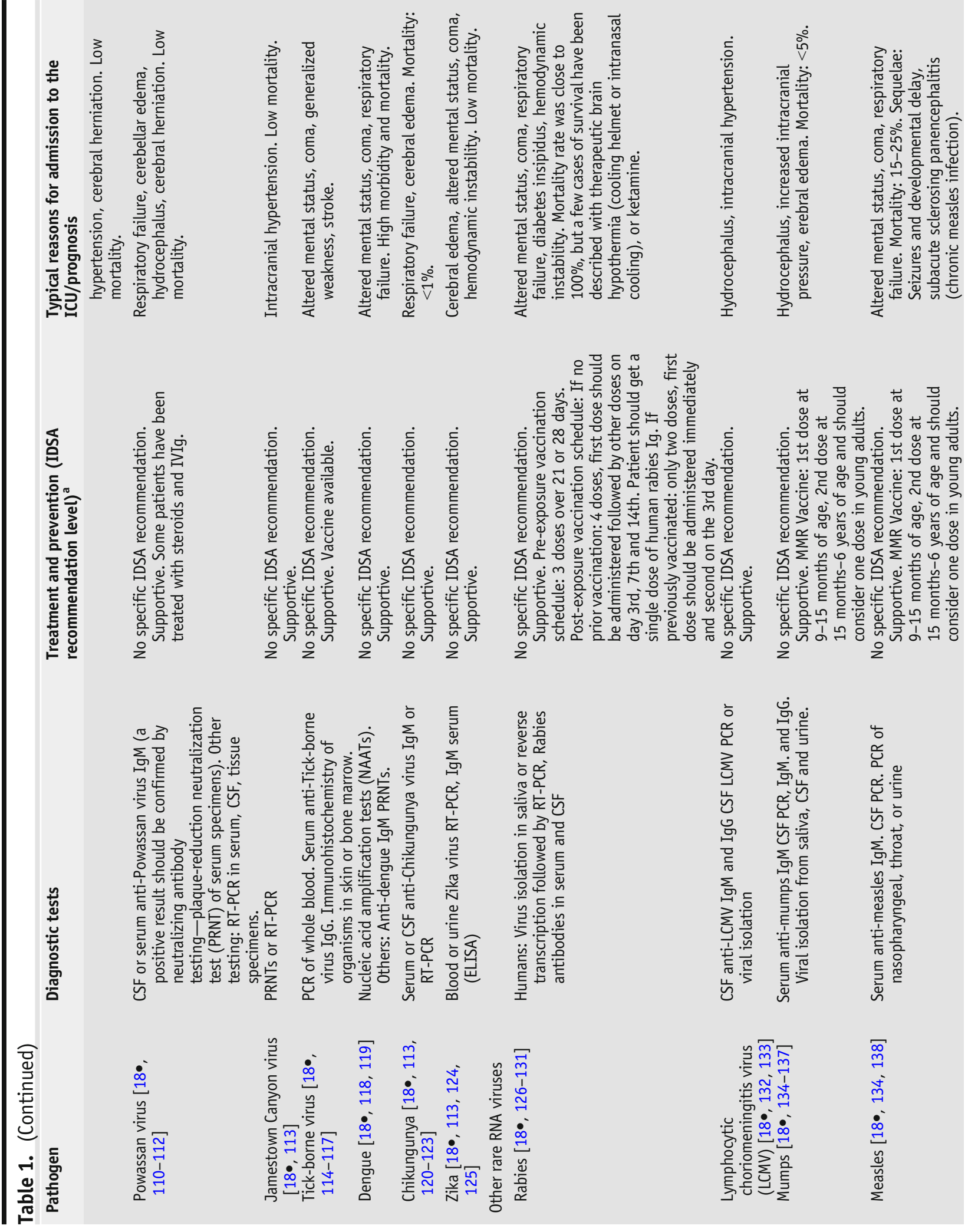


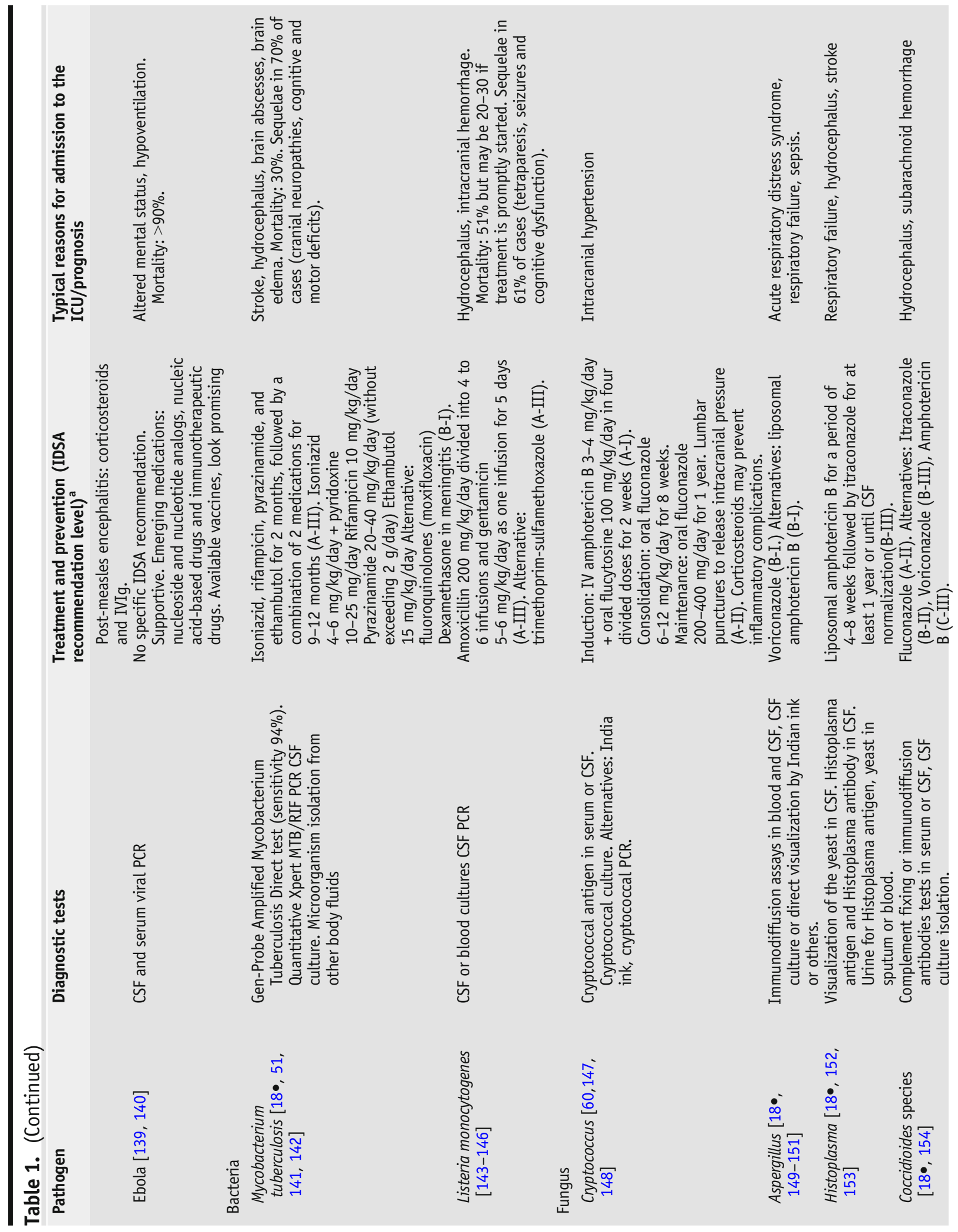




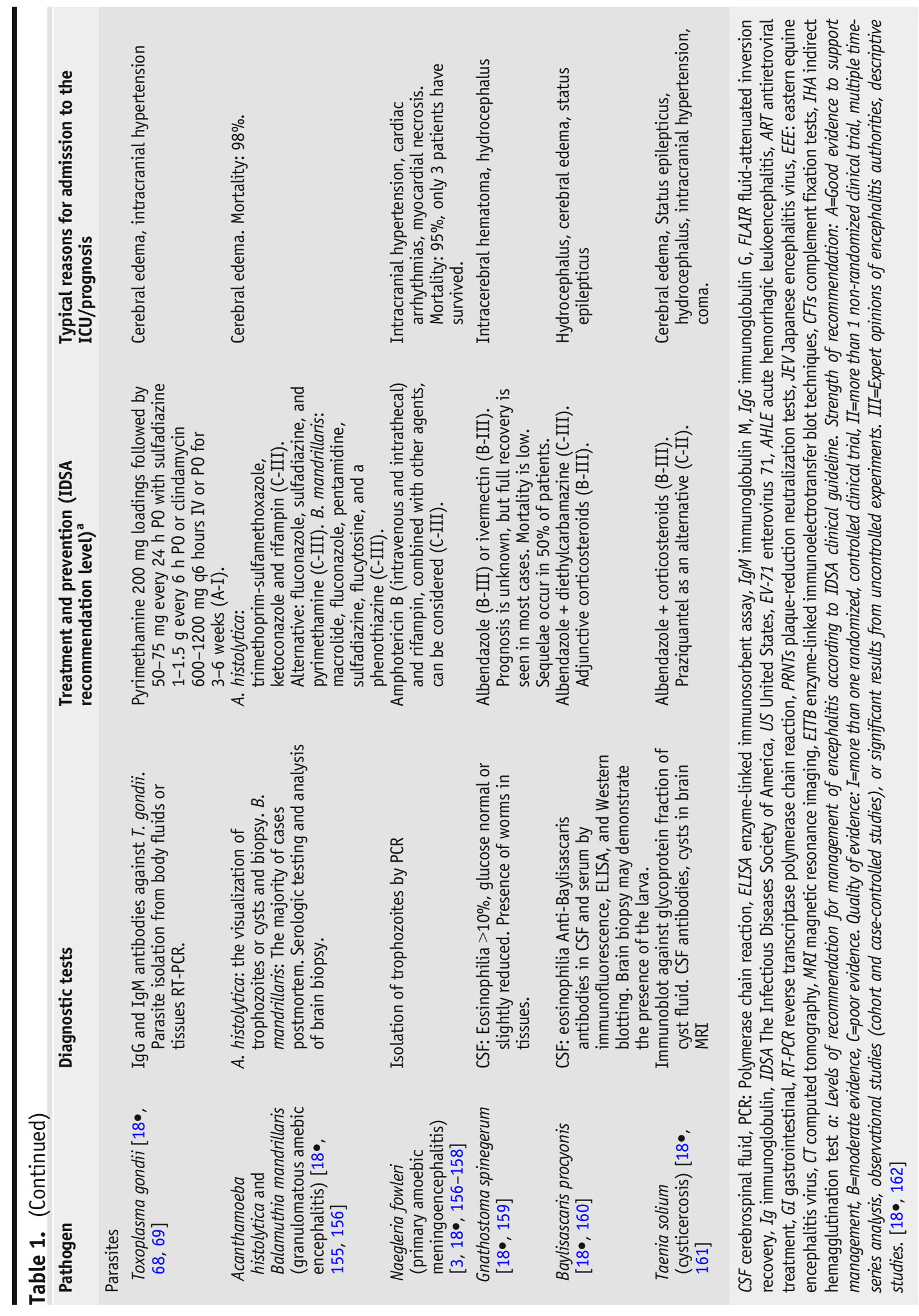


Metagenomic NGS offers a comprehensive evaluation of viral, bacterial, parasitic, and fungal infections by deep sequencing of the RNA or DNA of fluids or tissue samples. This method involves isolation and sequencing of RNA and DNA from CSF specimens, followed by computational analysis for identification of non-human pathogens based on the known sequences of viruses, bacteria or fungi available in genomic databases. [ $9 \bullet \bullet]$ Advantages of mNGS include its unbiased approach as it does not require prior assumptions regarding the type of pathogen and thus allows for the discovery of more potential and unusual pathogens (e.g. leptospirosis, dengue, toxoplasmosis, Balamuthia mandrillaris). [170-173] In a prospective study of over 200 patients ( 58 of whom had an infection of the nervous system), mNGS identified 32 (55\%) patients with infection, 13 of whom $(22 \%)$ were not diagnosed by hospital clinical testing. [ $9 \bullet \bullet$ ] In addition, mNGS may complement conventional testing in ruling out co-infections and supporting clinical diagnoses, such as in autoimmune encephalitis, where providers may more readily initiate systemic immunosuppression in the setting of results excluding an occult infection.

Clinicians have adopted the "tumor board" concept from oncology to discuss mNGS results to guide their clinical decisions. Even though the usefulness of mNGS results is still under study, this novel technique provides more information than just "positive" and "negative" results from methods such as PCR, cultures or serologic testing. [9••] However, disadvantages of mNGS include the potential of false-positive results due to sample contamination either by normal body flora, environment, or laboratory procedures or misidentification errors in the computational bioinformatics approach. [174] In addition, mNGS interpretation remains challenging as a lack of standardized thresholds for reporting a positive test and the adoption of conservative clinical references have consequently resulted in a high percentage of false-

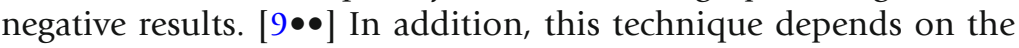
presence of nucleic acids in CSF, a factor that may limit diagnosis of pathogens that have a short-lived presence in the CNS or have a very low "pathogen-load" in the CSF such as WNV, VZV, or neurosyphilis. In fact, $26(44 \%)$ of 58 infections described in the prospective study previously discussed, were not diagnosed with either mNGS or con-

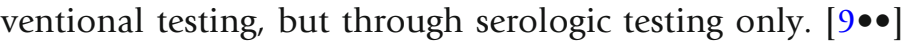

In terms of costs, the median length of hospitalization stay of an encephalitis patient ranges from 3 to 13 days, with average costs of care being \$ 60,000 . [175, 176] Major contributing factors to costs of care and length of hospitalization are difficulty in the identification of culprit pathogens and the extensive evaluations employed to rule out infection. [177] mNGS may prove to be a useful diagnostic tool for rapid pathogen identification; however, current associated costs and availability of testing have delayed its widespread adoption. Recently, demographic and health care criteria have been explored in specific patient populations where mNGS may prove costeffective in evaluating for infectious meningitis and encephalitis. These include those patients who had undergone a neurosurgical procedure, were admitted to the ICU, were co-infected with HIV-1 or had undergone a previous organ transplant, were less than 1 year of age, or had been hospitalized for at least 2 days. [175] Further study is needed to truly determine 
the benefits and associated costs of mNGS to guide its broader adoption in the evaluation of patients with suspected infectious encephalitis.

Neurophysiological tools in the ICU

In cases of persistently altered consciousness, continuous EEG (cEEG) monitoring for at least $24 \mathrm{~h}$ is helpful to exclude intermittent seizures and status epilepticus. [71] Approximately 50\% of patients with nonconvulsive seizures will be detected by conventional EEG. In contrast, cEEG detects about $95 \%$ of nonconvulsive seizures cases between 24 and 48 h of recording. [178] The American Clinical Neurophysiology Society recommends EEG if there is persistent altered mental status despite treatment; unknown etiology of altered consciousness; and evidence of generalized, lateralized, and bilateral independent periodic discharges. [179]

\section{Complications of infectious encephalitis in the ICU}

Critical care management in the setting of encephalitis is frequently driven by depressed mental status, seizures, respiratory failure, stroke, hydrocephalus and intracranial hypertension due to cerebral edema. Adequate management of these complications is critical to minimize both morbidity and mortality and ensure improved clinical outcomes.

\section{Encephalopathy and decreased mental status}

A great majority of patients with infectious encephalitis develop encephalopathy and decreased mental status; however, only $15 \%$ are unconscious and require intensive care management. [3] Encephalitis can involve the diencephalon and brainstem structures, affecting the reticular activating system (RAS), or may also produce cerebral edema and subsequent intracranial hypertension interfering with the normal cerebral blood perfusion, both leading to altered consciousness and coma.

Seizures are a frequent manifestation of infectious encephalitis, mostly as a result of cerebral cortex involvement. For instance, seizures affect about $85 \%$ of patients with JEV and $10 \%$ of patients with WNV infections. [180] Status epilepticus (SE) and refractory status epilepticus (RSE) are common complications of encephalitis, particularly nonconvulsive seizures.

SE is a continuing seizure activity for more than 5 minutes or repetitive seizures without recovery among episodes. Rapid seizure control is critical to decreasing the likelihood of additional neurologic damage or more systemic complications such as rhabdomyolysis, lactic acidosis, aspiration, and pulmonary problems. [181]

Acute treatment of seizures includes the initial standard of care with IV lorazepam administered $2 \mathrm{mg}$ every $1-2 \mathrm{~min}$ (maximum dose $0.1 \mathrm{mg} / \mathrm{kg}$ ). A second agent should be administered if lorazepam is inadequate to abort 
seizures. These options include phenytoin, fosphenytoin, levetiracetam, valproate, and lacosamide. [181]

If convulsive seizure activity persists despite the use of two drugs, then the patient is likely in RSE. In this scenario, the patient should be sedated with an IV medication, for example, midazolam $(1-2 \mathrm{mg} / \mathrm{kg} / \mathrm{h})$ or propofol $(50-80$ $\mu \mathrm{g} / \mathrm{kg} / \mathrm{min}$ ), and intubated. [3] Quantitative EEG is useful for titrating therapy and evaluating seizure control. There is no consensus for an ideal level of EEG suppression; nevertheless, the recommendation is to reduce burst suppression pattern and decrease seizure recurrence through deep sedation for at least one day. [3]

Recent non-controlled clinical studies suggest that an alternative therapy for uncontrollable seizures with inadequate response to antiepileptic medications is the ketogenic diet (KD). It is a high-fat and low carbohydrate diet that induces ketone bodies and has been useful in drug-resistant epilepsy in children and adults. The KD has been used in patients with Rasmussen encephalitis, antiNMDAR encephalitis, and post-infectious mycoplasma encephalitis with success, and it is a potential therapy option. [182] A recent study in a tertiary referral center demonstrated seizure control in $73 \%$ of patients with super RSE after two days of treatment with the diet. [183••]

Neuromuscular weakness is a frequent sequela in critically ill patients, affecting more than $25 \%$ of patients in the ICU. It may be caused by a myopathy, polyneuropathy or a combination of both. The most common form of neuromuscular weakness is ICU-associated myopathy. This condition is characterized by the loss of myosin, myofibrillar disorganization, and necrosis. [184, 185] The use of glucocorticoids appears to be related to this process. [186] ICUrelated polyneuropathy is the second most frequent cause of weakness and it is probably associated with microvascular compromise that produces ischemia and axonal degeneration. [187]

Clinical presentation includes flaccid quadriparesis typically affecting proximal more than distal muscles, weaning failure from mechanical ventilator, hyporeflexia, and impaired sensation. The presentation, examination, and electrodiagnostic tests (nerve conduction studies and electromyography; NCS and EMG) may help with the diagnosis. In the setting of myopathy, NCS and EMG demonstrate low motor amplitudes with a prolonged action potential, and decreased phrenic motor amplitudes, while sensory function is usually preserved. In contrast, neuropathy is frequently characterized by decreased motor and sensory amplitudes on NGS, fibrillation potentials on EMG, and reduced phrenic motor amplitudes. [188]

Management is centered on the treatment of the principal medical condition, physical therapy, decreasing sedation, and avoiding complications (e.g., pulmonary embolism and deep venous thrombosis). Despite the paucity of evidence related to the use of corticosteroids, the recommendation is to reduce these medications as soon as possible.

\section{Cerebral edema and intracranial hypertension}

Cerebral edema, intracranial hypertension, and herniation are potential complications of encephalitis, with a mortality rate of approximately 60\%. [189, 
190] Cerebral edema is defined as swelling of the brain that may become lifethreatening when the intracranial pressure reaches levels above $25 \mathrm{~cm}$ water, leading to ischemia and herniation. Many infectious encephalitides, such as HSV and VZV encephalitis, can lead to vasogenic edema and intracranial hypertension. [3] In suspected cases, diagnostic imaging or intracranial pressure measurement may be considered.

Patients with cerebral edema and associated intracranial hypertension treated aggressively have better outcomes. [191, 192] Aggressive care includes the use of osmotic agents such as mannitol or hypertonic saline, sedation, induced hypothermia, hyperventilation, surgical brain decompression, control of fever, and management of seizures. Other general recommendations include reducing the period that the patient remains in a supine position, elevating the head at least $30^{\circ}$, and avoiding hyponatremia. [3]

Implementation of corticosteroids has been proposed as adjunctive therapy; however, clinical data is still limited to support their use. Despite this fact, combination therapy of acyclovir and corticosteroids may be considered in VZV and EBV encephalitis. [18•, 193, 194] In addition, consensus regarding corticosteroids dosage and duration in encephalitis does not exist, but prednisone at $1 \mathrm{mg} / \mathrm{kg}$ for 3-5 days has been described for VZV encephalitis. [195]

\section{Stroke}

Cerebrovascular disease occurs in a variety of CNS infections, including encephalitis, often requiring intensive care with a generally poor prognosis. [196] Strokes in the setting of infectious encephalitis may be associated with the primary infectious disease process and specific pathogen (e.g., HSV, VZV) or due to secondary factors such as increased brain edema and transtentorial herniations. Most of the infection associated cases of stroke have been reported with HSV, VZV, and CMV infections. The presence of a stroke may distract the medical team from the correct diagnosis and treatment. Thus, it is essential to consider other alternative diagnoses when the clinical picture is atypical. Treatment of the infection is the primary approach for this complication.

\section{Hydrocephalus}

Hydrocephalus is the result of an obstruction in the CSF pathway or alteration of CSF production that more frequently affects children and adolescents. [197] In infectious processes, the mechanism appears to be mediated by the desquamation of ependyma with a posterior mechanical obstruction or cross-linking between ependymal cells. [198] Also, the accumulation of particles in the aqueduct, the narrowest structure of the CSF system, stimulates this process. Numerous cases have been reported with HSV-2 infection. [199] Hydrocephalus may be life-threatening and should be treated with medical and surgical interventions. [200]

\section{Conclusion}

Infectious encephalitides include a diverse group of pathogens, including viruses, which together represent a frequent type of encephalitis. The prompt diagnosis and adequate treatment of the primary infection, as well as the management of associated complications, are crucial for better outcomes and 
fewer neurological sequelae. Intensivists play a fundamental role in the management of patients with infectious encephalitis, particularly in the initial evaluation and treatment as well as the management of complications. ICUlevel management is critical, given the high associated rate of mortality and the critical role of ICU-level intervention in outcomes and survival.

\section{Compliance with Ethical Standards}

Conflict of Interest

The authors report no conflicts of interest with this work.

Human and Animal Rights and Informed Consent

This article does not contain any studies with human or animal subjects performed by any of the authors.

\section{References and Recommended Reading}

Papers of particular interest, published recently, have been highlighted as:

- Of importance

$\bullet \quad$ Of major importance

1. Halperin JJ. Diagnosis and management of acute encephalitis. Handb Clin Neurol. 2017;140:337-47.

2. $\quad$ Venkatesan A, Tunkel AR, Bloch KC, Lauring AS, Sejvar J, Bitnun A, et al. Case definitions, diagnostic algorithms, and priorities in encephalitis: consensus statement of the international encephalitis consortium. Clin Infect Dis. 2013;57(8):1114-2.

This is a helpful consensus statement when evaluating a patient with infectious encephalitis.

3. Kramer AH. Viral encephalitis in the ICU. Crit Care Clin. 2013;29(3):621-49.

4. Dubey D, Pittock SJ, Kelly CR, McKeon A, Lopez-Chiriboga AS, Lennon VA, et al. Autoimmune encephalitis epidemiology and a comparison to infectious encephalitis. Ann Neurol. 2018;83(1):166-77.

5. de Seze J, Debouverie M, Zephir H, Lebrun C, Blanc F, Bourg $\mathrm{V}$, et al. Acute fulminant demyelinating disease: a descriptive study of 60 patients. Arch Neurol. 2007;64(10):1426-32.

6. Pruss H. Postviral autoimmune encephalitis: manifestations in children and adults. Curr Opin Neurol. 2017;30(3):327-33.

7. Salama S, Khan M, Pardo S, Izbudak I, Levy M. MOG antibody-associated encephalomyelitis/encephalitis. Mult Scler. 2019;25(11):1427-33.

8. Bloch KC, Glaser CA. Encephalitis surveillance through the emerging infections program, 1997-2010. Emerg Infect Dis. 2015;21(9):1562-7.

9.• Wilson MR, Sample HA, Zorn KC, Arevalo S, Yu G, Neuhaus J, et al. Clinical Metagenomic Sequencing for
Diagnosis of Meningitis and Encephalitis. N Engl J Med. 2019;380(24):2327-4.

This is an important study which demonstrates the potential utility of metagenomic sequencing in diagnosing infectious meningitis and encephalitis.

10. Bhatt S, Gething PW, Brady OJ, Messina JP, Farlow AW, Moyes CL, et al. The global distribution and burden of dengue. Nature. 2013;496(7446):504-7.

11. Beckham JD, Tyler KL. Arbovirus infections. Continuum (Minneap Minn). 2015;21(6 Neuroinfectious Disease):1599-611.

12. Munoz LS, Garcia MA, Gordon-Lipkin E, Parra B, Pardo $\mathrm{CA}$. Emerging viral infections and their impact on the global burden of neurological disease. Semin Neurol. 2018;38(2):163-75.

13. Ryu W-S, Ryu W-S. Part II. DNA Viruses. In: Molecular Virology of Human Pathogenic Viruses: Academic Press; 2017. p. 83-4.

14. Bradshaw MJ, Venkatesan A. Herpes simplex Virus-1 encephalitis in adults: pathophysiology, diagnosis, and management. Neurotherapeutics. 2016;13(3):493508.

15. Sellner J, Trinka E. Seizures and epilepsy in herpes simplex virus encephalitis: current concepts and future directions of pathogenesis and management. J Neurol. 2012;259(10):2019-30.

16. Tyler KL. Herpes simplex virus infections of the central nervous system: encephalitis and meningitis, including Mollaret's. Herpes. 2004;11(Suppl 2):57A-64A.

17. Burns J, Redfern DR, Esiri MM, McGee JO. Human and viral gene detection in routine paraffin embedded 
tissue by in situ hybridisation with biotinylated probes: viral localisation in herpes encephalitis. J Clin Pathol. 1986;39(10):1066-73.

18. Tunkel AR, Glaser CA, Bloch KC, Sejvar JJ, Marra $\mathrm{CM}$, Roos KL, et al. The management of encephalitis: clinical practice guidelines by the Infectious Diseases Society of America. Clin Infect Dis. 2008;47(3):303-2.

A valuable resource for the evaluation and management of patients with infectious encephalitis.

19. Pahud BA, Glaser CA, Dekker CL, Arvin AM, Schmid DS. Varicella zoster disease of the central nervous system: epidemiological, clinical, and laboratory features 10 years after the introduction of the varicella vaccine. J Infect Dis. 2011;203(3):316-23.

20. Jayaraman K, Rangasami R, Chandrasekharan A. Magnetic resonance imaging findings in viral encephalitis: a pictorial essay. J Neurosci Rural Pract. 2018;9(4):556-60.

21. Grahn A, Studahl M. Varicella-zoster virus infections of the central nervous system - prognosis, diagnostics and treatment. J Inf Secur. 2015;71(3):281-93.

22. De Broucker T, Mailles A, Chabrier S, Morand P, Stahl J$P$. Acute varicella zoster encephalitis without evidence of primary vasculopathy in a case-series of 20 patients. Clin Microbiol Infect. 2012;18(8):808-19.

23. Poscher ME. Successful treatment of varicella zoster virus meningoencephalitis in patients with AIDS: report of four cases and review. AIDS. 1994;8(8):1115-7.

24. Poltronieri $\mathrm{P}$, Sun B, Mallardo M. RNA viruses: RNA roles in pathogenesis, Coreplication and Viral Load. Curr Genomics. 2015;16(5):327-35.

25. Jain S, Patel B, Bhatt GC. Enteroviral encephalitis in children: clinical features, pathophysiology, and treatment advances. Pathog Glob Health.

2014;108(5):216-22.

26. Chaudhuri A, Kennedy PGE. Diagnosis and treatment of viral encephalitis. Postgrad Med J. 2002;78(924):575-83.

27. Huang CC, Liu CC, Chang YC, Chen CY, Wang ST, Yeh TF. Neurologic complications in children with enterovirus 71 infection. N Engl J Med. 1999;341(13):93642.

28. Taravilla CN, Pérez-Sebastián I, Salido AG, Serrano CV, Extremera VC, Rodríguez AD, et al. Enterovirus A71 infection and neurologic disease, Madrid, Spain, 2016. Emerg Infect Dis. 2019;25(1):25-32.

29. Perez-Velez CM, Anderson MS, Robinson CC, McFarland EJ, Nix WA, Pallansch MA, et al. Outbreak of neurologic enterovirus type 71 disease: a diagnostic challenge. Clin Infect Dis. 2007;45(8):950-7.

30. Lee KY. Enterovirus 71 infection and neurological complications. Korean J Pediatr. 2016;59(10):395401.

31. Jang S, Suh S, Ha SM, Byeon JH, Eun B-L, Lee YH, et al. Enterovirus 71-related encephalomyelitis: usual and unusual magnetic resonance imaging findings. Neuroradiology. 2012;54(3):239-45.
32. Davis LE, Beckham JD, Tyler KL. North American encephalitic arboviruses. Neurol Clin. 2008;26(3):72757 ix.

33. Venkatesan A, Murphy OC. Viral encephalitis. Neurol Clin. 2018;36(4):705-24.

34. Boucher A, Herrmann JL, Morand P, Buzele R, Crabol Y, Stahl JP, et al. Epidemiology of infectious encephalitis causes in 2016. Med Mal Infect. 2017;47(3):22135.

35. Debiasi RL, Tyler KL. West Nile virus meningoencephalitis. Nat Clin Pract Neurol. 2006;2(5):264-75.

36. Sonneville R, Ferrand H, Tubach F, Roy C, Bouadma L, Klein IF, et al. Neurological complications of HIV infection in critically ill patients: clinical features and outcomes. J Infect. 2011;62(4):301-8 [Internet]. Available from: http://www.sciencedirect.com/science/ article/pii/S0163445311000375.

37. Finocchio T, Coolidge W, Johnson T. The ART of antiretroviral therapy in critically Ill patients with HIV. J Intensive Care Med. 2018;34(11-12):897-909. https://doi.org/10.1177/0885066618803871.

38. Shelburne SA, Montes M, Hamill RJ. Immune reconstitution inflammatory syndrome: more answers, more questions. J Antimicrob Chemother. 2006;57(2):16770.

39. Hirsch HH, Kaufmann G, Sendi P, Battegay M. Immune reconstitution in HIV-infected patients. Clin Infect Dis. 2004;38(8):1159-66.

40. Ratnam I, Chiu C, Kandala N-B, Easterbrook PJ. Incidence and risk factors for immune reconstitution inflammatory syndrome in an ethnically diverse HIV type 1 -infected cohort. Clin Infect Dis. 2006;42(3):418-27.

41. Muller M, Wandel S, Colebunders R, Attia S, Furrer H, Egger M. Immune reconstitution inflammatory syndrome in patients starting antiretroviral therapy for HIV infection: a systematic review and meta-analysis. Lancet Infect Dis. 2010;10(4):251-61.

42. Grant PM, Komarow L, Andersen J, Sereti I, Pahwa S, Lederman MM, et al. Risk factor analyses for immune reconstitution inflammatory syndrome in a randomized study of early vs. deferred ART during an opportunistic infection. PLoS One. 2010;5(7):e11416.

43. Murdoch DM, Venter WDF, Feldman C, Van Rie A. Incidence and risk factors for the immune reconstitution inflammatory syndrome in HIV patients in South Africa: a prospective study. AIDS. 2008;22(5):601-10.

44. Pepper DJ, Marais S, Maartens G, Rebe K, Morroni C, Rangaka MX, et al. Neurologic manifestations of paradoxical tuberculosis-associated immune reconstitution inflammatory syndrome: a case series. Clin Infect Dis. 2009;48(11):e96-107.

45. Murray R, Mallal S, Heath C, French M. Cerebral mycobacterium avium infection in an HIV-infected patient following immune reconstitution and cessation of therapy for disseminated mycobacterium avium complex infection. Eur J Clin Microbiol Infect Dis. 2001;20(3):199-201. 
46. Manabe YC, Campbell JD, Sydnor E, Moore RD. Immune reconstitution inflammatory syndrome: risk factors and treatment implications. J Acquir Immune Defic Syndr. 2007;46(4):456-62.

47. Honnorat E, De Broucker T, Mailles A, Stahl JP. Encephalitis due to Mycobacterium tuberculosis in France. Med Mal Infect. 2013;43(6):230-8.

48. Granerod J, Ambrose HE, Davies NW, Clewley JP, Walsh AL, Morgan D, et al. Causes of encephalitis and differences in their clinical presentations in England: a multicentre, population-based prospective study. Lancet Infect Dis. 2010;10(12):835-44.

49. Kingkaew N, Sangtong B, Amnuaiphon W, Jongpaibulpatana J, Mankatittham W, Akksilp S, et al. HIVassociated extrapulmonary tuberculosis in Thailand: epidemiology and risk factors for death. Int J Infect Dis. 2009;13(6):722-9.

50. Garg RK, Sinha MK. Tuberculous meningitis in patients infected with human immunodeficiency virus. J Neurol. 2011;258(1):3-13.

51. Stahl JP. Tuberculous encephalitis. In: Sener A, Erdem $\mathrm{H}$, editors. Extrapulmonary tuberculosis. Cham: Springer International Publishing; 2019. p. 121-30. https://doi.org/10.1007/978-3-030-04744-3_9.

52. Erdem H, Ozturk-Engin D, Elaldi N, Gulsun S, Sengoz G, Crisan A, et al. The microbiological diagnosis of tuberculous meningitis: results of Haydarpasa-1 study. Clin Microbiol Infect. 2014;20(10):O600-8.

53. Metcalf T, Soria J, Montano SM, Ticona E, Evans CA, Huaroto L, et al. Evaluation of the GeneXpert MTB/RIF in patients with presumptive tuberculous meningitis. PLoS One. 2018;13(6):e0198695.

54. Bahr NC, Nuwagira E, Evans EE, Cresswell FV, Bystrom PV, Byamukama A, et al. Diagnostic accuracy of Xpert MTB/RIF ultra for tuberculous meningitis in HIV-infected adults: a prospective cohort study. Lancet Infect Dis. 2018;18(1):68-75.

55. Patel VB, Theron G, Lenders L, Matinyena B, Connolly $\mathrm{C}$, Singh R, et al. Diagnostic accuracy of quantitative PCR (Xpert MTB/RIF) for tuberculous meningitis in a high burden setting: a prospective study. PLoS Med. 2013;10(10):e1001536.

56. Denkinger CM, Schumacher SG, Boehme CC, Dendukuri N, Pai M, Steingart KR. Xpert MTB/RIF assay for the diagnosis of extrapulmonary tuberculosis: a systematic review and meta-analysis. Eur Respir J.

2014;44(2):435-46.

57. Prasad K, Singh MB, Ryan H. Corticosteroids for managing tuberculous meningitis. Cochrane Database Syst Rev. 2016;4:CD002244.

58. Prasad KSMB, Ryan H. Corticosteroids for managing tuberculous meningitis. Cochrane Database Syst Rev. 2016;(4). https://doi.org/10.1002/14651858. CD002244.pub4.

59. Srikanta D, Santiago-Tirado FH, Doering TL. Cryptococcus neoformans: historical curiosity to modern pathogen. Yeast. 2014;31(2):47-60.
60. Malhotra A, Rao Q, Kelly S, Schwartz D, Chow R. A Rare presentation of cryptococcal meningoencephalitis in 0061 $\mathrm{n}$ immunocompetent individual. Clin Pract. 2017;7:1002.

61. Brouwer AE, Rajanuwong A, Chierakul W, Griffin GE, Larsen RA, White NJ, et al. Combination antifungal therapies for HIV-associated cryptococcal meningitis: a randomised trial. Lancet. 2004;363(9423):1764-7.

62. Graybill JR, Sobel J, Saag M, van Der Horst C, Powderly W, Cloud G, et al. Diagnosis and management of increased intracranial pressure in patients with AIDS and cryptococcal meningitis. The NIAID mycoses study group and AIDS cooperative treatment groups. Clin Infect Dis. 2000;30(1):47-54.

63. Darras-Joly C, Chevret S, Wolff M, Matheron S, Longuet $\mathrm{P}$, Casalino E, et al. Cryptococcus neoformans infection in France: epidemiologic features of and early prognostic parameters for 76 patients who were infected with human immunodeficiency virus. Clin Infect Dis. 1996;23(2):369-76.

64. Beardsley J, Wolbers M, Kibengo FM, Ggayi A-BM, Kamali A, Cuc NTK, et al. Adjunctive dexamethasone in HIV-associated cryptococcal meningitis. N Engl J Med. 2016;374(6):542-54.

65. Luft BJ, Remington JS. Toxoplasmic encephalitis in AIDS. Clin Infect Dis. 1992;15(2):211-22.

66. Jones JL, Hanson DL, Dworkin MS, Alderton DL, Fleming PL, Kaplan JE, et al. Surveillance for AIDSdefining opportunistic illnesses, 1992-1997. MMWR CDC Surveill Summ. 1999;48(2):1-22.

67. Jones JL, Roberts JM. Toxoplasmosis hospitalizations in the United States, 2008, and trends, 1993-2008. Clin Infect Dis. 2012;54(7):e58-61.

68. Levy RM, Rosenbloom S, Perrett LV. Neuroradiologic findings in AIDS: a review of 200 cases. AJR Am J Roentgenol. 1986;147(5):977-83.

69. Senocak E, Oguz KK, Ozgen B, Kurne A, Ozkaya $G$, Unal S, et al. Imaging features of CNS involvement in AIDS. Diagn Interv Radiol. 2010;16(3):193-200.

70. Dina TS. Primary central nervous system lymphoma versus toxoplasmosis in AIDS. Radiology. 1991;179(3):823-8.

71. Fitch MT, van de Beek D. Drug insight: steroids in CNS infectious diseases-new indications for an old therapy. Nat Clin Pract Neurol. 2008;4(2):97-104.

72. Lee BY, Newberg AB, Liebeskind DS, Kung J, Alavi A. FDG-PET findings in patients with suspected encephalitis. Clin Nucl Med. 2004;29(10):620-5.

73. Probasco JC, Solnes L, Nalluri A, Cohen J, Jones $\mathrm{KM}$, Zan E, et al. Abnormal brain metabolism on FDG-PET/CT is a common early finding in autoimmune encephalitis. Neurol Neuroimmunol Neuroinflamm. 2017;4(4):e35.

This retrospective study describes FDG-PET scan patterns in patients with autoimmune encephalitis. These findings may be helpful ruling out autoimmune etiologies. 
74. Wong KK, Tolia B, Bohnen N. Chronic sequelae of herpes simplex encephalitis demonstrated on interictal F-18 FDG PET/CT. Clin Nucl Med. 2008;33(6):443-4.

75. Righi E, Carnelutti A, Muser D, Zaja F, Lucchini E, Pea F, et al. Successful treatment and FDG-PET/CT monitoring of HHV-6 encephalitis in a non-neutropenic patient: case report and literature review. J Neuro-Oncol. 2017;23(6):908-12.

76. Coiffard B, Guedj E, Daumas A, Leveque P, Villani P. Brain PET metabolic abnormalities in a case of varicella-zoster virus encephalitis. Clin Nucl Med. 2014;39(9):e389-91.

77. Jaquet $\mathrm{P}$, de Montmollin E, Dupuis C, Sazio C, Conrad $\mathrm{M}$, Susset V, et al. Functional outcomes in adult patients with herpes simplex encephalitis admitted to the ICU: a multicenter cohort study. Intensive Care Med. 2019;45(8):1103-11. https://doi.org/10.1007/ s00134-019-05684-0.

78. Abdelmalik PA, Ambrose T, Bell R. Herpes Simplex Viral Encephalitis Masquerading as a Classic Left MCA Stroke. Case Rep Neurol Med. 2015;2015:673724.

79. Van Den Tooren HK, Bharambe V, Silver N, Michael BD. Herpes simplex virus encephalitis in a patient receiving ustekinumab associated with extensive cerebral oedema and brainshift successfully treated by immunosuppression with dexamethasone. BMJ Case Rep. 2019;12(8).

80. Kusulja M, Santini M. Decompressive craniectomy as salvage treatment in herpes simplex encephalitis: Two case reports. Int J Infect Dis. 2018;73:49-51.

81. Hagiya H, Kimura M, Miyamoto T, Otsuka F. Systemic varicella-zoster virus infection in two critically ill patients in an intensive care unit. Virol J. 2013;10:225.

82. Mpaka M, Karantanas AH, Zakynthinos E. Atypical presentation of varicella-zoster virus encephalitis in an immunocompetent adult. Heart Lung. 2008;37(1):61-6.

83. Prosch S, Schielke E, Reip A, Meisel H, Volk HD, Einhaupl KM, et al. Human cytomegalovirus (HCMV) encephalitis in an immunocompetent young person and diagnostic reliability of HCMV DNA PCR using cerebrospinal fluid of nonimmunosuppressed patients. J Clin Microbiol. 1998;36(12):3636-40.

84. Newcomb G, Mariuz P, Lachant D. CMV Encephalitis/ Radiculitis: The Difficulty in Diagnosing in an Intubated Patient. Case Rep Crit Care. 2019;2019:8067648.

85. Zarlasht F, Salehi M, Abu-Hishmeh M, Khan M. Encephalitis treatment - a case report with longterm follow-up of EBV PCR in cerebrospinal fluid. Intern J Gen Med. 2017;10:371-3.

86. Rodrigo-Armenteros $\mathrm{P}$, Kapetanovic-Garcia $\mathrm{S}$, Anton-Mendez L, Gomez-Muga JJ, Rio EB-D, Fernandez-Cuesta $\mathrm{MA}$, et al. Akinetic mutism and status epilepticus due to Epstein Barr virus encephalitis. Clin Neurol Neurosurg. 2019;185:105492.
87.

90. Gewurz BE, Marty FM, Baden LR, Katz JT. Human herpesvirus 6 encephalitis. Curr Infect Dis Rep. 2008;10(4):292-9.

91. Shahani L. HHV-6 encephalitis presenting as status epilepticus in an immunocompetent patient. BMJ Case Rep. 2014;2014.

92. Al-Zubeidi D, Thangarajh M, Pathak S, Cai C, Schlaggar BL, Storch GA, et al. Fatal Human Herpesvirus 6-Associated Encephalitis in Two Boys With Underlying POLG Mitochondrial Disorders. Pediatr Neurol. 2014;51(3):448-52 Available from: http://www. sciencedirect.com/science/article/pii/ S0887899414002124.

93. Long L, Xu L, Xiao Z, Hu S, Luo R, Wang H, et al. Neurological complications and risk factors of cardiopulmonary failure of EV-A71-related hand, foot and mouth disease. Sci Rep. 2016;6:23444.

94. Gika AD, Rich P, Gupta S, Neilson DE, Clarke A. Recurrent acute necrotizing encephalopathy following influenza A in a genetically predisposed family. Dev Med Child Neurol. 2010;52(1):99-102.

95. Alsolami A, Shiley K. Successful Treatment of Influenza-Associated Acute Necrotizing Encephalitis in an Adult Using High-Dose Oseltamivir and Methylprednisolone: Case Report and Literature Review. Open forum Infect Dis. 2017;4(3):ofx145.

96. Wendel KA, McArthur JC. Acute Meningoencephalitis in Chronic Human Immunodeficiency Virus (HIV) Infection: Putative Central Nervous System Escape of HIV Replication. Clin Infect Dis. 2003;37(8):1107-11. https://doi.org/10.1086/378300.

97. Ambrosioni J, Artigues F, Nicolás D, Peñafiel J, Agüero F, Manzardo C, et al. Neurological involvement in patients with acute/recent HIV-1 infection. A case-control study. J Neurovirol. 2017;23(5):679-85. https://doi.org/10.1007/ s13365-017-0548-6.

98. Fan E, Needham DM, Brunton J, Kern RZ, Stewart TE. West Nile virus infection in the intensive care unit: a case series and literature review. Can Respir J. 2004;11(5):354-8.

99. Flores Anticona EM, Zainah H, Ouellette DR, Johnson LE. Two case reports of neuroinvasive west nile virus infection in the critical care unit. Case Rep Infect Dis. 2012;2012:839458. 
100. Yu YA, Bolton M. A Case of Eastern Equine Encephalitis. Clin Pediatr (Phila). 2018;58(2):245-6. https:// doi.org/10.1177/0009922818806842.

101. Venkat H, Adams L, Sunenshine R, Krow-Lucal E, Levy C, Kafenbaum T, et al. St. Louis encephalitis virus possibly transmitted through blood transfusion-Arizona, 2015. Transfusion. 2017;57(12):2987-94.

102. Chiu CY, Coffey LL, Murkey J, Symmes K, Sample HA, Wilson MR, et al. Diagnosis of Fatal Human Case of St. Louis Encephalitis Virus Infection by Metagenomic Sequencing, California, 2016. Emerg Infect Dis. 2017;23(10):1964-8.

103. Wasay M, Diaz-Arrastia R, Suss RA, Kojan S, Haq A, Burns D, et al. St Louis Encephalitis: A Review of 11 Cases in a 1995 Dallas, Tex, Epidemic. JAMA Neurol. 2000;57(1):114-8. https://doi.org/10. 1001/archneur.57.1.114.

104. Cerna F, Mehrad B, Luby J, Burns D, Fleckenstein J. St. Louis encephalitis and the substantia nigra: MR imaging evaluation. AJNR Am J Neuroradiol. 1999;20:1281-3.

105. Hills SL, Griggs AC, Fischer M. Japanese encephalitis in travelers from non-endemic countries, 1973-2008. Am J Trop Med Hyg. 2010;82(5):930-6.

106. Sunwoo J-S, Lee S-T, Jung K-H, Park K-I, Moon J, Jung $\mathrm{K}-\mathrm{Y}$, et al. Clinical Characteristics of Severe Japanese Encephalitis: A Case Series from South Korea. Am J Trop Med Hyg. 2017;97(2):369-75.

107. Byrd BD. La Crosse Encephalitis: A Persistent Arboviral Threat in North Carolina. N C Med J. 2016;77(5):330-3.

108. Teleron ALA, Rose BK, Williams DM, Kemper SE, McJunkin JE. La Crosse Encephalitis: An Adult Case Series. Am J Med. 2016;129(8):881-4 Available from: http://www.sciencedirect.com/science/article/pii/ S0002934316303497.

109. McJunkin JE, de los Reyes EC, Irazuzta JE, Caceres MJ, Khan RR, Minnich LL, et al. La Crosse Encephalitis in Children. N Engl J Med. 2001;344(11):801-7. https://doi.org/10.1056/NEJM200103153441103.

110. Hermance ME, Thangamani S. Powassan Virus: An Emerging Arbovirus of Public Health Concern in North America. Vector Borne Zoonotic Dis. 2017;17(7):453-62.

111. Birge J, Sonnesyn S. Powassan virus encephalitis, Minnesota, USA. Emerg Infect Dis. 2012;18(10):1669-71.

112. Piantadosi A, Rubin DB, McQuillen DP, Hsu L, Lederer PA, Ashbaugh CD, et al. Emerging Cases of Powassan Virus Encephalitis in New England: Clinical Presentation, Imaging, and Review of the Literature. Clin Infect Dis. 2015;62(6):707-13. https://doi.org/ $10.1093 / \mathrm{cid} / \mathrm{civ} 1005$.

113. Pastula DM, Smith DE, Beckham JD, Tyler KL. Four emerging arboviral diseases in North America: Jamestown Canyon, Powassan, chikungunya, and Zika virus diseases. J Neurovirol. 2016;22(3):257-60.

114. Kaiser R. Tick-borne encephalitis. Infect Dis Clin N Am. 2008;22(3):561-75.
115. Kuivanen S, Smura T, Rantanen K, Kämppi L, Kantonen J, Kero M, et al. Fatal Tick-Borne Encephalitis Virus Infections Caused by Siberian and European Subtypes, Finland, 2015. Emerg Infect Dis. 2018;24:946-8.

116. Eleftheriou A, Lundin F, Petropoulos EA. Tick-borne Encephalitis: Stroke-like Presentation. J Stroke Cerebrovasc Dis. 2019;28(8):e119-22 Available from: http://www.sciencedirect.com/science/article/pii/ S1052305719302654.

117. Horger M, Beck R, Fenchel M, Ernemann U, Nägele T, Brodoefel $\mathrm{H}$, et al. Imaging Findings in Tick-Borne Encephalitis With Differential Diagnostic Considerations. Am J Roentgenol. 2012;199(2):420-7. https:// doi.org/10.2214/AJR.11.7911.

118. Li G-H, Ning Z-J, Liu Y-M, Li X-H. Neurological Manifestations of Dengue Infection. Front Cell Infect Microbiol. 2017;7:449.

119. Soni BK, Das DSR, George RA, Aggarwal R, Sivasankar R. MRI features in dengue encephalitis: A case series in South Indian tertiary care hospital. Indian J Radiol imag. 2017;27:125-8.

120. Koeltz A, Lastere S, Jean-Baptiste S. Intensive Care Admissions for Severe Chikungunya Virus Infection, French Polynesia, Emerging infectious diseases. 2018;24:794-6.

121. Ortíz Quezada JA, Hesse H, Gonzalez E, Molina L, Duran C, Lorenzana I. Chikungunya virus encephalitis in the new world. J Neurol Sci. 2017;381:1007. https://doi.org/10.1016/j.jns.2017.08.2841.

122. Mehta R, Gerardin P, de Brito CAA, Soares CN, Ferreira MLB, Solomon T. The neurological complications of chikungunya virus: A systematic review. Rev Med Virol. 2018;28(3):e1978.

123. Gérardin P, Couderc T, Bintner M, Tournebize P, Renouil M, Lémant J, et al. Chikungunya virus-associated encephalitis. Neurology. 2016;86(1):94 LP102 Available from: http://n.neurology.org/content/ 86/1/94.abstract.

124. Pradhan F, Burns JD, Agameya A, Patel A, Alfaqih M, Small JE, et al. Case Report: Zika Virus Meningoencephalitis and Myelitis and Associated Magnetic Resonance Imaging Findings. Am J Trop Med Hyg. 2017;97(2):340-3.

125. Schwartzmann PV, Ramalho LNZ, Neder L, Vilar FC, Ayub-Ferreira SM, Romeiro MF, et al. Zika Virus Meningoencephalitis in an Immunocompromised $\mathrm{Pa}-$ tient. Mayo Clin Proc. 2017;92(3):460-6.

126. Mahadevan A, Suja MS, Mani RS, Shankar SK. Perspectives in Diagnosis and Treatment of Rabies Viral Encephalitis: Insights from Pathogenesis. Neurotherapeutics. 2016;13(3):477-92.

127. Jassi P, Attri A, Dhawan R, Kakkar C, Saggar K. MR imaging in rabies encephalitis: A rare entity. Annals Ind Acad Neurol. 2016;19:125-8.

128. Manesh A, Mani RS, Pichamuthu K, Jagannati M, Mathew V, Karthik R, et al. Case Report: Failure of Therapeutic Coma in Rabies Encephalitis. Am J Trop Med Hyg. 2018;98(1):207-10. 
129. Recovery of a patient from clinical rabies-Wisconsin, 2004. MMWR Morb Mortal Wkly Rep. 2004;53(50):1171-3.

130. Lockhart BP, Tsiang H, Ceccaldi PE, Guillemer S. Ketamine-Mediated Inhibition of Rabies Virus Infection in vitro and in Rat Brain. Antivir Chem Chemother. 1991;2(1):9-15. https://doi.org/10.1177/ 095632029100200102.

131. Jackson AC. Therapy of human rabies. Adv Virus Res. 2011;79:365-75.

132. Bonthius DJ. Lymphocytic choriomeningitis virus: an underrecognized cause of neurologic disease in the fetus, child, and adult. Semin Pediatr Neurol. 2012;19(3):89-95.

133. Tanveer F, Younas M, Fishbain J. Lymphocytic choriomeningitis virus meningoencephalitis in a renal transplant recipient following exposure to mice. Transpl Infect Dis. 2018;20(6):e13013.

134. Woo AR, Lee HY, Lim MK, Kang YH, Cho SG, Choi $\mathrm{SH}$, et al. Magnetic Resonance Imaging Findings of Mumps Meningoencephalitis with Bilateral Hippocampal Lesions without Preceding Acute Parotitis: A Case Report. Korean J Radiol. 2017;18(2):378-82.

135. Viola L, Chiaretti A, Castorina M, Tortorolo L, Piastra M, Villani A, et al. Acute hydrocephalus as a consequence of mumps meningoencephalitis. Pediatr Emerg Care. 1998;14(3):212-4.

136. Gonzalez-Gil J, Zarrabeitia MT, Altuzarra E, SanchezMolina I, Calvet R. Hydrocephalus: a fatal late consequence of mumps encephalitis. J Forensic Sci. 2000;45(1):204-7.

137. Rajma J, Arun AC. Severe Complications of Mumps. Indian pediatrics. 2017;54:689.

138. Fox A, Hung TM, Wertheim H, Hoa LNM, Vincent A, Lang B, et al. Acute measles encephalitis in partially vaccinated adults. PLoS One. 2013;8(8):e71671.

139. Billioux BJ, Smith B, Nath A. Neurological Complications of Ebola Virus Infection. Neurotherapeutics. 2016;13(3):461-70.

140. Jacobs M, Rodger A, Bell DJ, Bhagani S, Cropley I, Filipe A, et al. Late Ebola virus relapse causing meningoencephalitis: a case report. Lancet (London, England). 2016;388(10043):498-503.

141. Kalita J, Misra UK, Ranjan P. Predictors of long-term neurological sequelae of tuberculous meningitis: a multivariate analysis. Eur J Neurol. 2007;14(1):33-7.

142. Cardenas G, Soto-Hernandez JL, Orozco RV, Silva EG, Revuelta R, Amador JLG. Tuberculous brain abscesses in immunocompetent patients: management and outcome. Neurosurgery. 2010;67(4):1081-7 discussion 1087.

143. Le Monnier A, Abachin E, Beretti J-L, Berche P, Kayal S. Diagnosis of Listeria monocytogenes meningoencephalitis by real-time PCR for the hly gene. J Clin Microbiol. 2011;49(11):3917-23.

144. Castellazzi ML, Marchisio P, Bosis S. Listeria monocytogenes meningitis in immunocompetent and healthy children: a case report and a review of the literature. Ital J Pediatr. 2018;44(1):152.
145. Mansbridge CT, Grecu I, Li Voon Chong JS, Vandervelde C, Saeed K. Two cases of listeria rhombencephalitis. ID Cases. 2018;11:22-5.

146. Armstrong RW, Fung PC. Brainstem encephalitis (rhombencephalitis) due to Listeria monocytogenes: case report and review. Clin Infect Dis.

1993;16(5):689-702.

147. Rhein J, Bahr NC, Hemmert AC, Cloud JL, Bellamkonda S, Oswald C, et al. Diagnostic performance of a multiplex PCR assay for meningitis in an HIV-infected population in Uganda. Diagn Microbiol Infect Dis. 2016;84(3):268-73.

148. Troncoso A, Fumagalli J, Shinzato R, Gulotta H, Toller M, Bava J. CNS cryptococcoma in an HIV-positive patient. J Int Assoc Physicians AIDS Care (Chic). 2002;1(4):131-3.

149. Desai SD, Seth S, Shah A, Vaishnav B. Aspergillus meningoencephalitis in a patient with human immunodeficiency virus infection: Normal cerebrospinal fluid does not does not mean absence of meningitis. Indian J Sex Trans Dis AIDS. 2016;37:185-9.

150. Patterson TF, Thompson GR III, Denning DW, Fishman JA, Hadley S, Herbrecht R, et al. Practice Guidelines for the Diagnosis and Management of Aspergillosis: 2016 Update by the Infectious Diseases Society of America. Clin Infect Dis. 2016;63(4):e1-60. https://doi.org/10.1093/cid/ciw326.

151. Taccone FS, Van den Abeele A-M, Bulpa P, Misset B, Meersseman W, Cardoso T, et al. Epidemiology of invasive aspergillosis in critically ill patients: clinical presentation, underlying conditions, and outcomes. Crit Care. 2015;19(1):7.

152. Wheat J, Myint T, Guo Y, Kemmer P, Hage C, Terry C, et al. Central nervous system histoplasmosis: Multicenter retrospective study on clinical features, diagnostic approach and outcome of treatment. Medicine (Baltimore). 2018;97(13):e0245.

153. Hariri OR, Minasian T, Quadri SA, Dyurgerova A, Farr S, Miulli DE, et al. Histoplasmosis with Deep CNS Involvement: Case Presentation with Discussion and Literature Review. J Neurol Surg Reports.

2015;76:e167-72.

154. Lammering JC, Iv M, Gupta N, Pandit R, Patel MR. Imaging Spectrum of CNS Coccidioidomycosis: Prevalence and Significance of Concurrent Brain and Spinal Disease. Am J Roentgenol. 2013;200(6):133446. https://doi.org/10.2214/AJR.12.9264.

155. Walker MD, Zunt JR. Neuroparasitic infections: cestodes, trematodes, and protozoans. Semin Neurol. 2005;25(3):262-77.

156. Visvesvara GS, Moura H, Schuster FL. Pathogenic and opportunistic free-living amoebae: Acanthamoeba spp., Balamuthia mandrillaris, Naegleria fowleri, and Sappinia diploidea. FEMS Immunol Med Microbiol. 2007;50(1):1-26.

157. Grace E, Asbill S, Virga K. Naegleria fowleri: pathogenesis, diagnosis, and treatment options. Antimicrob Agents Chemother. 2015;59(11):6677-81. 
158. Ferrante A. Free-living amoebae: pathogenicity and immunity. Parasite Immunol. 1991;13(1):31-47.

159. Ramirez-Avila L, Slome S, Schuster FL, Gavali S, Schantz PM, Sejvar J, et al. Eosinophilic meningitis due to Angiostrongylus and Gnathostoma species. Clin Infect Dis. 2009;48(3):322-7.

160. Gavin PJ, Kazacos KR, Shulman ST. Baylisascariasis. Clin Microbiol Rev. 2005;18(4):703-18.

161. Carpio A. Neurocysticercosis: an update. Lancet Infect Dis. 2002;2(12):751-62.

162. The periodic health examination. Canadian Task Force on the Periodic Health Examination. Can Med Assoc J. 1979;121(9):1193-254.

163. Dorsett M, Liang SY. Diagnosis and Treatment of Central Nervous System Infections in the Emergency Department. Emerg Med Clin North Am. 2016;34(4):917-42.

164. Josephson SA, Miller BL. Confusion and Delirium. In: Kasper D, Fauci A, Hauser S, Longo D, Jameson JL, Loscalzo J, editors. Harrison's Principles of Internal Medicine, $19 \mathrm{e}$ [Internet]. New York: McGraw-Hill Education; 2014. Available from: accessmedicine. mhmedical.com/content.aspx?aid=1120787223.

165. Honnorat J, Antoine J-C. Paraneoplastic neurological syndromes. Orphanet J Rare Dis. 2007;2:22.

166. Biofire. Film Array Meningitis/Encephalitis (ME) Panel Instruction Booklet.

167. Lee SH, Chen S-Y, Chien J-Y, Lee T-F, Chen J-M, Hsueh P-R. Usefulness of the FilmArray meningitis/ encephalitis $(\mathrm{M} / \mathrm{E})$ panel for the diagnosis of infectious meningitis and encephalitis in Taiwan. J Microbiol Immunol Infect. 2019;52(5):760-8.

168. Leber AL, Everhart K, Balada-Llasat J-M, Cullison J, Daly J, Holt S, et al. Multicenter Evaluation of BioFire FilmArray Meningitis/Encephalitis Panel for Detection of Bacteria, Viruses, and Yeast in Cerebrospinal Fluid Specimens. J Clin Microbiol. 2016;54(9):225161.

169.• Brown JR, Bharucha T, Breuer J. Encephalitis diagnosis using metagenomics: application of next-generation sequencing for undiagnosed cases. J Infect. 2018;76(3):225-4.

This systematic review describes the important role of NGS in the diagnosis of encephalitis of unknown etiology, especially in cases of chronic or recurrent presentation.

170. Johnson TP, Larman HB, Lee M-H, Whitehead SS, Kowalak J, Toro C, et al. Chronic Dengue Virus Panencephalitis in a Patient with Progressive Dementia with Extrapyramidal Features. Ann Neurol. 2019;86(5):695-703.

171. Wilson MR, Naccache SN, Samayoa E, Biagtan M, Bashir H, Yu G, et al. Actionable diagnosis of neuroleptospirosis by next-generation sequencing. $\mathrm{N}$ Engl J Med. 2014;370(25):2408-17.

172. Greninger AL, Messacar K, Dunnebacke T, Naccache $\mathrm{SN}$, Federman S, Bouquet J, et al. Clinical metagenomic identification of Balamuthia mandrillaris encephalitis and assembly of the draft genome: the continuing case for reference genome sequencing. Genome Med. 2015;7:113.

173. Hu Z, Weng X, Xu C, Lin Y, Cheng C, Wei H, et al. Metagenomic next-generation sequencing as a diagnostic tool for toxoplasmic encephalitis. Ann Clin Microbiol Antimicrob. 2018;17(1):45.

174. Miller S, Chiu C, Rodino KG, Miller MB. PointCounterpoint: Should We Be Performing Metagenomic Next-Generation Sequencing for Infectious Disease Diagnosis in the Clinical Laboratory? J Clin Microbiol. 2020;58(3):1-7.

175. Fulton BD, Proudman DG, Sample HA, Gelfand JM, Chiu CY, DeRisi JL, et al. Exploratory analysis of the potential for advanced diagnostic testing to reduce healthcare expenditures of patients hospitalized with meningitis or encephalitis. PLoS One. 2020;15(1):e0226895.

176. Vora NM, Holman RC, Mehal JM, Steiner CA, Blanton J, Sejvar J. Burden of encephalitis-associated hospitalizations in the United States, 1998-2010. Neurology. 2014;82(5):443-51.

177. Britton PN, Eastwood K, Paterson B, Durrheim DN, Dale RC, Cheng AC, et al. Consensus guidelines for the investigation and management of encephalitis in adults and children in Australia and New Zealand. Intern Med J. 2015;45(5):563-76.

178. Fogang Y, Legros B, Depondt C, Mavroudakis N, Gaspard N. Yield of repeated intermittent EEG for seizure detection in critically ill adults. Neurophysiol Clin. 2017;47(1):5-12.

179. Herman ST, Abend NS, Bleck TP, Chapman KE, Drislane FW, Emerson RG, et al. Consensus statement on continuous EEG in critically ill adults and children, part I: indications. J Clin Neurophysiol. 2015;32(2):87-95.

180. Sawlani V. Diffusion-weighted imaging and apparent diffusion coefficient evaluation of herpes simplex encephalitis and Japanese encephalitis. J Neurol Sci. 2009;287(1-2):221-6.

181. Rossetti AO, Lowenstein DH. Management of refractory status epilepticus in adults: still more questions than answers. Lancet Neurol. 2011;10(10):922-30.

182. Thakur KT, Probasco JC, Hocker SE, Roehl K, Henry B, Kossoff EH, et al. Ketogenic diet for adults in superrefractory status epilepticus. Neurology. 2014;82(8):665-70.

183.• Cervenka MC, Hocker S, Koenig M, Bar B, HenryBarron B, Kossoff EH, et al. Phase I/II multicenter ketogenic diet study for adult superrefractory status epilepticus. Neurology. 2017;88(10):938-4.

This prospective multicenter study shows the effectiveness and feasibility of a ketogenic diet on the treatment of adult patients with super-refractory status epilepticus. A possible clinical manifestation in the acute phase of encephalitis.

184. Di Giovanni S, Mirabella M, D'Amico A, Tonali P, Servidei S. Apoptotic features accompany acute quadriplegic myopathy. Neurology. 2000 Sep;55(6):854-8. 
185. Lacomis D, Giuliani MJ, Van Cott A, Kramer DJ. Acute myopathy of intensive care: clinical, electromyographic, and pathological aspects. Ann Neurol. 1996;40(4):645-54.

186. Mozaffar T, Haddad F, Zeng M, Zhang LY, Adams GR, Baldwin KM. Molecular and cellular defects of skeletal muscle in an animal model of acute quadriplegic myopathy. Muscle Nerve. 2007 Jan;35(1):55-65.

187. Latronico N, Peli E, Botteri M. Critical illness myopathy and neuropathy. Curr Opin Crit Care. 2005;11(2):126-32.

188. Douglass JA, Tuxen DV, Horne M, Scheinkestel CD, Weinmann M, Czarny D, et al. Myopathy in severe asthma. Am Rev Respir Dis. 1992;146(2):517-9.

189. Jha SK. Cerebral Edema and its Management. Med J, Armed Forces India. 2003;59(4):326-31.

190. Lan S-Y, Lin J-J, Hsia S-H, Wang H-S, Chiu C-H, Lin KL. Analysis of Fulminant Cerebral Edema in Acute Pediatric Encephalitis. Pediatr Neonatol. 2016;57(5):402-7.

191. Hayton E, Wakerley B, Bowler IC, Bogdanovic M, Adcock JE. Successful outcome of Epstein-Barr virus encephalitis managed with bilateral craniectomy, corticosteroids and aciclovir. Pract Neurol. 2012;12(4):234-7.

192. Wagner I, Staykov D, Volbers B, Kloska S, Dorfler A, Schwab S, et al. Therapeutic hypothermia for spaceoccupying Herpes simplex virus encephalitis. Minerva Anestesiol. 2011;77(3):371-4.

193. Jubelt B. Infectious Diseases of the Nervous System. In: Rosenberg RN, editor. Atlas of Clinical Neurology. London: Current Medicine Group; 2009. p. 441-515. https://doi.org/10.1007/978-1-57340-359-7_12.
194. Gilden D. Varicella zoster virus and central nervous system syndromes. Herpes. 2004;11(Suppl 2):89A$94 \mathrm{~A}$.

195. Solomon T, Michael BD, Smith PE, Sanderson F, Davies NWS, Hart IJ, et al. Management of suspected viral encephalitis in adults-Association of British Neurologists and British Infection Association National Guidelines. J Infect. 2012;64(4):347-73.

196. Chow FC, Marra CM, Cho TA. Cerebrovascular disease in central nervous system infections. Semin Neurol. 2011;31(3):286-306.

197. Hirsch JF, Hirsch E, Sainte Rose C, Renier D, PierreKhan A. Stenosis of the aqueduct of Sylvius. Etiology and treatment. J Neurosurg Sci. 1986;30(1-2):29-39.

198. Wolinsky JS. Mumps virus-induced hydrocephalus in hamsters. Ultrastructure of the chronic infection. Lab Investig. 1977;37(3):229-36.

199. Heppner PA, Schweder PM, Monteith SJ, Law AJJ. Acute hydrocephalus secondary to herpes simplex type II meningitis. J Clin Neurosci Off J Neurosurg Soc Australas. 2008;15(10):1157-9.

200. Suman V, Roy U, Panwar A, Raizada A. Japanese Encephalitis Complicated with Obstructive Hydrocephalus. J Clin Diagn Res. 2016;10(2):OD18-20.

\section{Publisher's Note}

Springer Nature remains neutral with regard to jurisdictional claims in published maps and institutional affiliations. 